\title{
Time-dependent effects of hypothermia on microglial activation and migration
}

\author{
Jung-Wan Seo ${ }^{1}$, Jong-Heon Kim¹, Jae-Hong Kim', Minchul Seo ${ }^{1}$, Hyung Soo Han², \\ Jaechan Park ${ }^{3}$ and Kyoungho Suk ${ }^{*}$
}

\begin{abstract}
Background: Therapeutic hypothermia is one of the neuroprotective strategies that improve neurological outcomes after brain damage in ischemic stroke and traumatic brain injury. Microglial cells become activated following brain injury and play an important role in neuroinflammation and subsequent brain damage. The aim of this study was to determine the time-dependent effects of hypothermia on microglial cell activation and migration, which are accompanied by neuroinflammation.
\end{abstract}

Methods: Microglial cells in culture were subjected to mild $\left(33^{\circ} \mathrm{C}\right)$ or moderate $\left(29^{\circ} \mathrm{C}\right)$ hypothermic conditions before, during, or after lipopolysaccharide (LPS) or hypoxic stimulation, and the production of nitric oxide (NO), proinflammatory cytokines, reactive oxygen species, and neurotoxicity was evaluated. Effects of hypothermia on microglial migration were also determined in in vitro as well as in vivo settings.

Results: Early-, CO-, and delayed-hypothermic treatments inhibited microglial production of inflammatory mediators to varying degrees: early treatment was the most efficient, and delayed treatment showed time-dependent effects. Delayed hypothermia also suppressed the mRNA levels of proinflammatory cytokines and iNOS, and attenuated microglial neurotoxicity in microglia-neuron co-cultures. Furthermore, delayed hypothermia reduced microglial migration in the Boyden chamber assay and wound healing assay. In a stab injury model, delayed local hypothermia reduced migration of microglia toward the injury site in the rat brain.

Conclusion: Taken together, our results indicate that delayed hypothermia is sufficient to attenuate microglial activation and migration, and provide the basis of determining the optimal time window for therapeutic hypothermia. Delayed hypothermia may be neuroprotective by inhibiting microglia-mediated neuroinflammation, indicating the therapeutic potential of post-injury hypothermia for patients with brain damages exhibiting some of the inflammatory components.

Keywords: Hypothermia, Microglia, Cell migration, Neuroinflammation, Neuroprotection

\section{Introduction}

Brain injury can be classified as direct disruption of the brain tissue and as secondary damage. The primary tissue damage that occurs at the moment of impact results in immediate necrotic cell death, impaired regulation of cerebral blood flow, and disruption of the blood-brain barrier (BBB) [1]. Secondary brain damage is defined as delayed injury including brain inflammatory responses

\footnotetext{
* Correspondence: ksuk@knu.ac.kr

'Department of Pharmacology, Brain Science \& Engineering Institute, CMRI, Kyungpook National University School of Medicine, 101 Dong-In, Daegu, Joong-gu 700-422, South Korea

Full list of author information is available at the end of the article
}

such as resident immune cell activation, peripheral blood cell infiltration, and edema formation [2,3]. After brain injury, necrotic cell debris can stimulate an initiation of inflammation, activation of phagocytic cells, and synthesis of inflammatory mediators, such as cytokines and chemokines [4-6]. The inflammatory mediators contribute to neuronal cell death, BBB disruption, and reactive gliosis involving activation of microglia and astrocytes [7,8]. Microglial cells, resident immune cells of the central nerve system (CNS), play a critical role in neuropathology following brain injury. In activated microglial cells responding to the injury, migration and phagocytosis are promoted, and inflammatory mediators 
including superoxide anion, nitric oxide (NO), and inflammatory cytokines, such as interleukin-1 beta (IL-1 $\beta$ ) and tumor necrosis factor alpha (TNF- $\alpha$ ), are released $[9,10]$.

Induced hypothermia is a therapeutic intervention to treat brain injuries $[11,12]$. The protective mechanisms of mild or moderate hypothermia include the reductions in excitatory neurotransmitters, apoptotic cell death, dysfunctional mitochondria, and suppression of protein synthesis [13,14]. Previous reports have shown that hypothermia inhibits microglia and brain inflammation, which may be the underlying mechanism of the neuroprotective effects of mild hypothermia [15-19]. Our previous work has also demonstrated that hypothermia decreases NO and cytokine generation by microglia [20-22]. Although hypothermic protection has been considered a result of the preservation of metabolic stores and suppression of several key events as outlined above, alternative protection mechanisms have been suggested, such as changes in gene expression and the upregulation of anti-apoptotic factors or a family of cold shock proteins [23-25]. Nevertheless, the protective mechanism of therapeutic hypothermia remains yet to be fully understood. Several reports have suggested that neurological outcomes of therapeutic hypothermia may depend on the duration or initiation of the cooling time. Earlier initiation of the cooling seems to give a better outcome [26-28]. However, optimal brain cooling conditions have yet to be defined.

In this study, we attempted to determine the optimal cooling conditions of therapeutic hypothermia using microglial cell culture as well as in vivo models by examining the time-dependent effect of hypothermia on: 1) microglial NO production and cytokine expression; 2) microglia-mediated neurotoxicity in a microglia-neuron co-culture model; and 3) migration of microglial cells in cultures as well as in vivo. Our results show that delayed hypothermia is sufficient to attenuate microglial activation, migration, and possibly subsequent neuroinflammation. Our results also provide the basis of the optimal time window for hypothermic treatment.

\section{Methods}

\section{Reagents and cell culture}

The following chemicals were obtained from Sigma Chemical Co. (St Louis, MO, USA): bacterial lipopolysaccharide (LPS) from Escherichia coli 0111:B4, hydrogen peroxide $\left(\mathrm{H}_{2} \mathrm{O}_{2}\right)$, and sodium nitroprusside (SNP). The immortalized BV-2 murine microglial cells [29] were maintained in DMEM (Lonza, Walkersville, MD, USA) containing $5 \%$ heat-inactivated fetal bovine serum (FBS) (Lonza) and gentamicin $(50 \mu \mathrm{g} / \mathrm{ml})$ (Gibco-BRL, Rockville, MD, USA) at $37^{\circ} \mathrm{C}$. Mouse primary microglia cultures were prepared by mild trypsinization from mixed glial cultures as previously described with minor modifications [30]. In brief, the forebrains of newborn ICR mice were chopped and dissociated by mechanical disruption using a nylon mesh. After in vitro culturing for 10 to 14 days in DMEM supplemented with $10 \%$ FBS, $100 \mathrm{U} / \mathrm{ml}$ penicillin, and $100 \mu \mathrm{g} / \mathrm{ml}$ streptomycin (Gibco-BRL), mixed glial cultures were incubated with a trypsin solution ( $0.25 \%$ trypsin, $1 \mathrm{mM}$ ethylenediamine tetraacetic acid (EDTA) in Hank's balanced salt solutions) diluted 1:4 in PBS containing $1 \mathrm{mM} \mathrm{CaCl}_{2}$ for 30 to 60 minutes. This resulted in the detachment of an upper layer of astrocytes in one piece, whereas microglia remained attached to the bottom of the culture flask. The detached layer of astrocytes was aspirated, and the remaining microglia were used for experiments. Primary astrocyte cultures were prepared from mixed glial cultures by differential shaking as previously described [31]. The B35 rat neuroblastoma cell line (ATCC, CRL-2754) [32] stably expressing enhanced GFP (EGFP) was maintained in DMEM containing 10 \% heat-inactivated FBS, penicillin $(100 \mathrm{U} / \mathrm{ml})$ and streptomycin $(100 \mu \mathrm{g} / \mathrm{ml})$ at $37{ }^{\circ} \mathrm{C}$ under a humidified atmosphere with $5 \% \mathrm{CO}_{2}$. Primary cultures of dissociated cerebral cortical neurons were prepared from embryonic day 20 (E20) ICR mice as described previously [33]. Cells were exposed to hypothermic conditions by placing them into cell culture incubators set to $33{ }^{\circ} \mathrm{C}$ or $29^{\circ} \mathrm{C}$. The actual hypothermic condition was confirmed by measuring the temperature of the media.

\section{Hypoxia}

Hypoxia was implemented as previously described with minor modifications [34]. To induce hypoxic conditions, cells were washed three times with deoxygenated PBS and DMEM containing FBS, and incubated in an anaerobic chamber (atmosphere of $95 \% \mathrm{~N}_{2} / 5 \% \mathrm{CO}_{2}, \mathrm{O}_{2}$ tension $<5 \%$ ) (Anaerobic System 1025, Forma Scientific Inc., Marietta, OH, USA) for the indicated time period. Reoxygenation was performed by exchanging the media with a fresh DMEM, and cells were transferred into a regular normoxic incubator ( $95 \%$ air, $5 \% \mathrm{CO}_{2}$ ) and the incubation continued for the indicated time periods.

\section{Nitrite quantification}

$\mathrm{NO}_{2}$ concentrations in culture supernatants were measured to assess NO production in microglial cells using the Griess reagent as previously described [35]. Fifty microliters of sample aliquots were mixed with $50 \mu \mathrm{l}$ of Griess reagent ( $1 \%$ sulfanilamide/0.1 \% naphthylethylene diamine dihydrochloride $/ 2 \%$ phosphoric acid) in a 96-well plate. The absorbance at $550 \mathrm{~nm}$ was measured on a microplate reader. $\mathrm{NaNO}_{2}$ was used as the standard to calculate the $\mathrm{NO}_{2}$ concentrations. 
Cell viability test

Cell viability was determined by the $3-(4,5-$ dimethylthiazol-2-yl)-2, 5-diphenyltetrazolium bromide (MTT) assay as previously described [36]. BV-2 microglial cells, primary microglia cultures, or B35-EGFP cells were seeded in triplicate at a density of 3 to $5 \times 10^{4}$ cells/well on a 96-well plate, and then treated as indicated. MTT was added to each well, and the cells were incubated for four hours at $37{ }^{\circ} \mathrm{C}$. After discarding the culture media, dimethyl sulfoxide (DMSO) was added to dissolve the formazan dye. Absorbance at $570 \mathrm{~nm}$ was measured with a microplate reader (Anthos Labtec Instruments, Wals, Austria).

Microglia/neuron co-cultures

Microglia/neuroblastoma co-culture was performed using BV-2 microglial cells or primary microglial cells $\left(1.5 \times 10^{4}\right)$ and B35 neuroblastoma cells $\left(3.75 \times 10^{4}\right)$ stably expressing EGFP (B35-EGFP) in a 96-well plate. LPS $(100 \mathrm{ng} / \mathrm{ml})$-stimulated BV-2 or primary microglial cells

Table 1 DNA sequences of the primers used for RT-PCR.

\begin{tabular}{|c|c|c|c|c|}
\hline CDNAs & RT-PCR methods & Primer sequences & GenBank accession No. & RT-PCR product size (bp) \\
\hline Mouse & Traditional & Forward, 5'-GCA ACT GTT CCT GAA CTC-3' & NM_008361 & 382 \\
\hline$i-1 \beta$ & & Reverse, 5'-CTC GGA GCC TGT AGT GCA-3' & & \\
\hline Mouse & Real-Time & Forward, 5'-AGT TGC CTT CTT GGG ACT GA-3' & NM_008361 & 102 \\
\hline$i l-1 \beta$ & & Reverse, 5'-TCC ACG ATT TCC CAG AGA AC-3' & & \\
\hline Mouse & Traditional & Forward, 5'-CCC TTC CGA AGT TTC TGG CAG CAG C-3' & NM_010927 & 497 \\
\hline inos & & Reverse, 5'-GGC TGT CAG AGC CTC GTG GCT TTG G-3' & & \\
\hline Mouse & Real-Time & Forward, 5'-GCC ACC AAC AAT GGC AAC A-3' & NM_010927 & 103 \\
\hline inos & & Reverse, 5'-CGT ACC GGA TGA GCT GTG AAT T-3' & & \\
\hline Mouse & Traditional & Forward, 5'-CAT CTT CTC AAA ATT CGA GTG ACA A-3' & NM_013693 & 411 \\
\hline $\operatorname{tnf}-a$ & & Reverse, 5'-ACT TGG GCA GAT TGA CCT CAG-3' & & \\
\hline Mouse & Real-Time & Forward, 5'-ATG GCC TCC CTC TCA GTT C-3' & NM_013693 & 104 \\
\hline $\operatorname{tnf}-a$ & & Reverse, 5'-TTG GTG GTT TGC TAC GAC GTG-3' & & \\
\hline Mouse & Real-Time & Forward, 5'- GCC CTC TCT СТC СТC TTG CT -3' & NM_013652 & 196 \\
\hline $\mathrm{CCl} 4$ & & Reverse, 5'- GTC TGC CTC TTT TGG TCA GG -3' & & \\
\hline Mouse & Real-Time & Forward, 5'- CGA CTG TTG CCT CTC GTA CA -3' & NM_016960 & 177 \\
\hline $\mathrm{CCl} 20$ & & Reverse, 5'- AGG AGG TTC ACA GCC CTT TT -3' & & \\
\hline Mouse & Real-Time & Forward, 5'-AAG TGC TGC CGT CAT TTT CT-3' & NM_021274 & 186 \\
\hline $\operatorname{cxc} 110$ & & Reverse, 5'-GTG GCA ATG ATC TCA ACA CG-3' & & \\
\hline Mouse & Real-Time & Forward, 5'-AGT TGC CTT CTT GGG ACT GA-3' & NM_031168 & 159 \\
\hline$i l-6$ & & Reverse, 5'-TCC ACG ATT TCC CAG AGA AC-3' & & \\
\hline Mouse & Real-Time & Forward, 5'- AAG GAC CAG CTG GAC AAC AT -3' & NM_010548 & 230 \\
\hline$i-10$ & & Reverse, 5'- TTT TCA CAG GGG AGA AAT CG 3' & & \\
\hline Mouse & Real-Time & Forward, 5'- CAT CGA TGA GCT GAT GCA GT -3' & M86672 & 163 \\
\hline$i-12$ & & Reverse, 5'- CAG ATA GCC CAT CAC CCT GT -3' & & \\
\hline Rat/mouse & Traditional & Forward, 5'-ACC ACA GTC CAT GCC ATC AC-3' & NM_008084 & 452 \\
\hline gapdh & & Reverse, 5'-TCC ACC ACC CTG TTG CTG TA-3' & & \\
\hline Mouse & Real-Time & Forward, 5'- TGG GCT ACA CTG AGC ACC AG -3' & NM_008084 & 171 \\
\hline gapdh & & Reverse, 5'- GGG TGT CGC TGT TGA AGT CA-3' & & \\
\hline Rat & Traditional & Forward, 5'-CTT TCA TCA CAC AGG ACA GG-3' & NM_031512.2 & 228 \\
\hline$i-1 \beta$ & & Reverse, 5'-GTG ATG TTC CCA TTA GAC AGC-3' & & \\
\hline Rat & Traditional & Forward, 5'-GAC GCC CCG GCC TTC CAA ATA AAT-3' & NM_012675.3 & 800 \\
\hline $\operatorname{tnf}-a$ & & Reverse, 5'-GCT GCC CCG ACT ATG TGC TCC TCA-3' & & \\
\hline Rat & Traditional & Forward, 5'-CAG ACA GTT TCT GGT CGA TGT CAT GA -3' & D44591 & 230 \\
\hline iNOS & & Reverse, 5'-CTG CAT GGA ACA GTA TAA GGC AAA C -3' & & \\
\hline
\end{tabular}

$\mathrm{bp}$, base pair; RT-PCR, reverse transcriptase-polymerase chain reaction. 
were co-cultured with B35 neuroblastoma cells under normothermic or hypothermic conditions. After 24 hours of incubation, viable B35-EGFP cells were counted to measure microglial neurotoxicity. Primary microglia and primary neuron co-cultures were done using culture inserts as described previously [37]. Cortical neuron cells were plated at a density of $5 \times 10^{4}$ cells per well in $150 \mu \mathrm{l}$ of medium in 96-well companion plates (Nunc, Roskilde, Denmark), and allowed to settle at $37{ }^{\circ} \mathrm{C}$ in $95 \%$ air $/ 5 \% \mathrm{CO}_{2}$. In a separate plate, primary microglia cells were plated at a density of $3 \times 10^{4}$ cells per insert in $80 \mu \mathrm{l}$ of medium in cell culture inserts $(0.2 \mu \mathrm{m}$ pore size) and allowed to settle at $37{ }^{\circ} \mathrm{C}$ overnight in $95 \%$ air/5\% $\mathrm{CO}_{2}$. Cell culture inserts containing the primary microglia cells were then inserted into the wells containing the cortical neuron cells before LPS and hypothermic treatment. For the collection of microglia conditioned media, primary microglia cells were plated at a density of $5 \times 10^{4}$ cells per well in $150 \mu$ l of medium in 96-well plates, and stimulated with LPS under either hypothermic or normothermic condition. Conditioned medium was collected from the cells as previously described [38], and centrifuged at 1,200 rpm for two minutes to remove cellular debris. Primary microglia conditioned medium was added to cortical neuron cells that were plated at a density of $5 \times 10^{4}$ cells per well in 96-well plates. Cortical neuron cells were further incubated for 24 hours in $95 \%$ air $5 \% \mathrm{CO}_{2}$ under either hypothermic or normothermic condition before viability measurement.

\section{Traditional or real-time reverse transcription-PCR}

Total RNA was extracted from cells or tissues with the TRIzol reagent (Invitrogen, Carlsbad, CA, USA), according to the manufacturer's instructions. Reverse transcription was done with Superscript II (Invitrogen) and oligo(dT) primers. PCR amplification, using specific primer sets, was carried out at an annealing temperature of $55^{\circ}$ to $60^{\circ} \mathrm{C}$ for 20 to 30 cycles. The PCR was performed with a DNA Engine Tetrad Peltier Thermal Cycler (MJ Research, Waltham, MA, USA). For the analysis of the PCR products, $10 \mu \mathrm{l}$ of each PCR product were electrophoresed on a $1 \%$ agarose gel and detected under UV light. GAPDH was used as an internal control. The real-time PCR was done with a One Step SYBR ${ }^{\circledR}$ PrimeScript $^{\text {mit }}$ RT-PCR Kit (Perfect Real Time; Takara Bio Inc., Tokyo, Japan) according to the manufacturer's instructions, followed by detection with an ABI Prism ${ }^{\circledR} 7500$ Sequence Detection System (Applied Biosystems, Foster City, CA, USA). Nucleotide sequences of the primers were based on published cDNA sequences (Table 1).

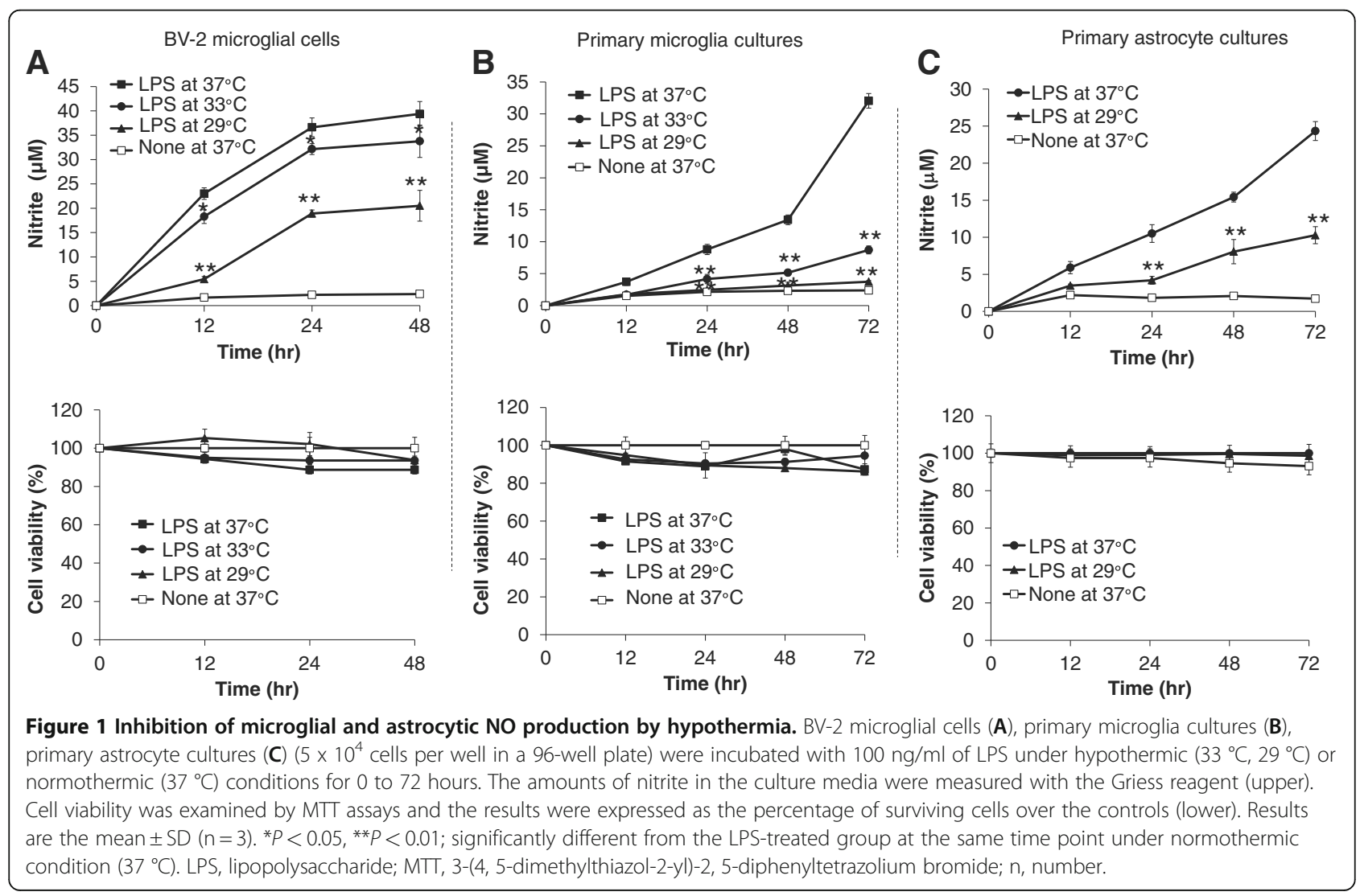




\section{Measurement of the production of reactive oxygen species (ROS)}

Production of microglial $\mathrm{H}_{2} \mathrm{O}_{2}$ was measured by the Amplex Red-horseradish peroxidase method (Molecular Probes, Eugene, OR, USA). Horseradish peroxidase (HRP, 0.1 unit $/ \mathrm{ml}$ ) catalyzes the $\mathrm{H}_{2} \mathrm{O}_{2}$-dependent oxidation of non-fluorescent Amplex Red $(50 \mu \mathrm{M})$ to fluorescent resorufin red [39]. Microglial cells were plated in 24-well culture plates at a density of $2 \times 10^{5}$ cells/well, and treated with LPS $(100 \mathrm{ng} / \mathrm{ml})$ for six hours under normothermic or hypothermic conditions. Afterwards, cells were detached and resuspended in N-2hydroxyethylpiperazine-N'-2-ethanesulfonic acid (HEPES buffer, Gibco-BRL) $\left(2 \times 10^{4}\right.$ microglial cells in $\left.50 \mu \mathrm{l}\right)$, to which $50 \mu \mathrm{l}$ of a mixture containing Amplex Red reagent and HRP were added in the wells of a 96-well fluorescence plate. After one hour of incubation at $37{ }^{\circ} \mathrm{C}$, fluorescence measurements were carried out at excitation/emission wavelengths of 544/590 nm. $\mathrm{H}_{2} \mathrm{O}_{2}$ of known concentrations was used to construct standard curves. ROS visualization was performed as described previously [40]. Microglial cells plated in 24well culture plates were treated under normothermia or hypothermia as described above, and incubated for 30 minutes at $37{ }^{\circ} \mathrm{C}$ in media containing $10 \mu \mathrm{M}$ of 5-(and 6-)chloromethyl-2,7'-dichlorodihydrofluorescein diacetate $\left(\mathrm{CMH}_{2} \mathrm{DCFDA}\right.$; Molecular Probes). The cultures were washed twice with PBS and subjected to fluorescence microscopic analysis. DCFDA-positive cells were counted from three randomly chosen microscopic fields (Olympus BX50). These three measurements were averaged and regarded as a data point.

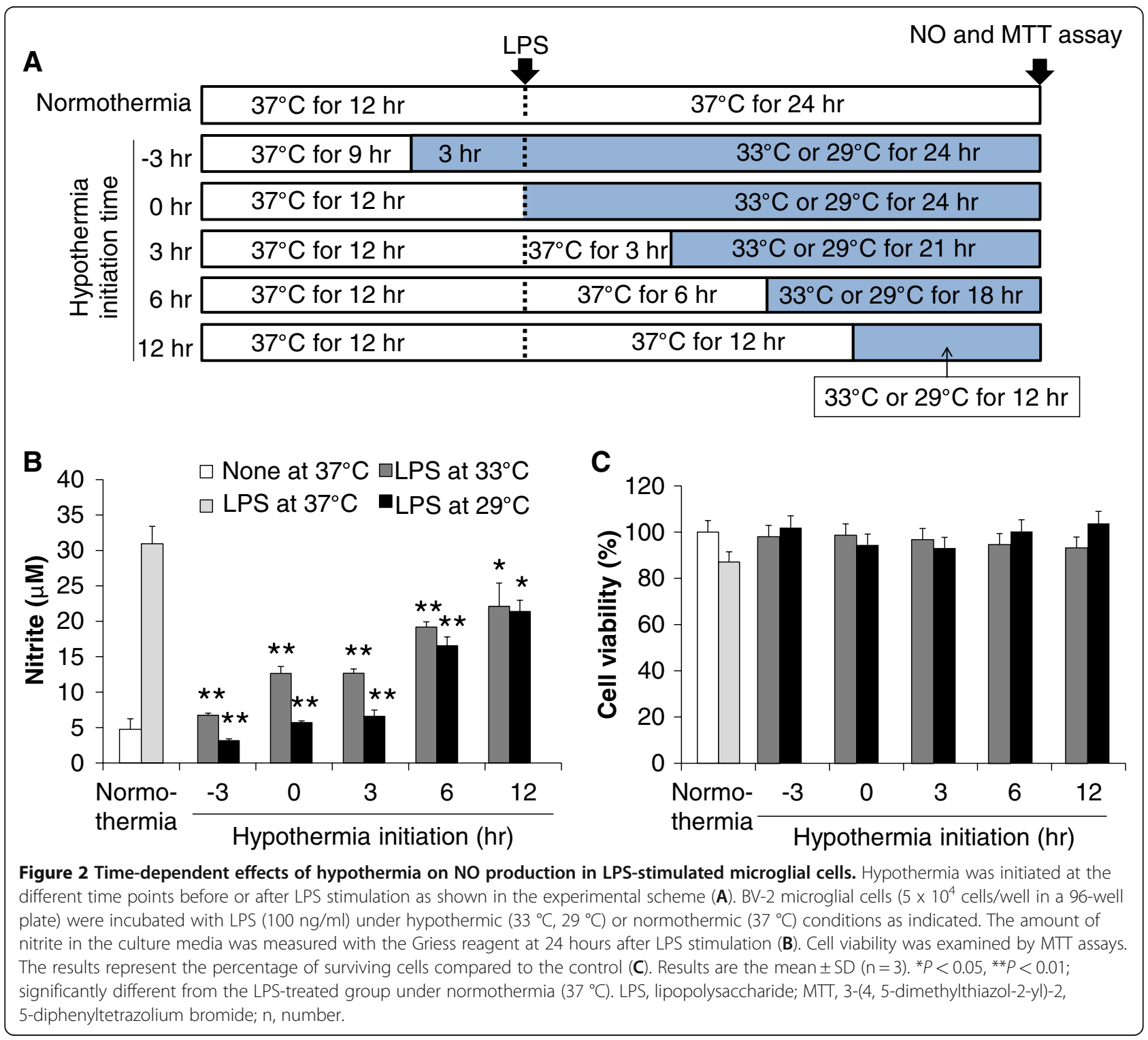




\section{In vitro cell migration assay}

Cell migration was determined with a 48-well Boyden chamber (NeuroProbe, Gaithersburg, MD, USA) according to the manufacturer's instructions [41]. Cells (1 x 10 cells per well) were added to the upper chamber separated from the bottom wells by polyvinylpyrrolidone-free polycarbonate filters $(8 \mu \mathrm{m}$ pore size; 25 x $80 \mathrm{~mm}$; NeuroProbe). Cells were incubated under normothermic or hypothermic conditions for the indicated time period. At the end of the incubation, non-migrating cells on the upper side of the membrane were removed with a cotton swab. Migrated cells on the lower side of the membrane were fixed with methanol for ten minutes and stained with Mayer's Hematoxylin (Dakocytomation, Glostrup, Denmark) for 20 minutes. Photomicrographs of five randomly chosen fields were taken (Olympus CK2; Tokyo, Japan) and cells were enumerated to calculate the average number of cells that had migrated. All migrated cells were counted, and the results are presented as the mean \pm SD of triplicates. The scratch wound healing assay was performed as previously described [42]. In brief, a scratch wound was created by using a $200 \mu \mathrm{l}$ pipette tip on confluent cell monolayers in 24-well culture plates, and placed into DMEM containing $5 \%$ FBS and $50 \mu \mathrm{g} / \mathrm{ml}$ gentamicin. Cells were incubated under normothermic or hypothermic conditions during migration of the monolayer into the cleared wound area. The wound area was observed by microscopy (Olympus $\mathrm{BX} 50)$. The relative cell migration distance was determined by measuring the wound width and subtracting this from the initial value as previously described: cell migration distance $=$ initial wound width - wound width at the time of measurement [43]. Three non-overlapping fields were selected and examined in each well (three wells per experimental group). The results are presented as an average fold increase of the migration distance.




In vivo cell migration assay

\section{Animal surgery}

Male Sprague-Dawley rats, with weights ranging from 300 to $350 \mathrm{~g}$ were purchased from the Samtako Co. (Osan, Korea). Rats were housed in individual cages at $22{ }^{\circ} \mathrm{C}$ on a 12 hour day/night cycle and freely allowed to access food and water. All surgical procedures were carried out according to the guidelines of the Kyungpook National University Animal Experiment Ethics Committee. Anesthetization was performed by intraperitoneal injection of tiletamine/zolazepam $(30 \mathrm{mg} / \mathrm{kg}$ (Zoletil; Virbac Laboratories, Carros, France)) and xylazine (10 mg/kg (Rompun; Bayer, Puteaux, France)), and animals were positioned in a stereotaxic apparatus (Stoelting, Wood Dale, IL, USA). Rats were placed on a homeothermic heat blanket (Harvard Apparatus Co., South Natick, MA, USA) at $37{ }^{\circ} \mathrm{C}$ to maintain normal body temperature during surgery. The skull was exposed by a skin incision, and small burr holes were drilled through the skull. The guide cannula was implanted at the stereotaxic coordinates of $-2 \mathrm{~mm}$ anterior to the bregma, $+3 \mathrm{~mm}$ lateral to the bregma, and $-1 \mathrm{~mm}$ below the dura using a $22 \mathrm{G}$ needle and cemented.

\section{Cooling coil}

Local cooling was performed using a cooling coil as previously described with slight modification [44]. Briefly, hypodermic tubing $(26 \mathrm{G})$ was bent into a spiral pattern measuring $4 \mathrm{~mm}$ in diameter and $0.5 \mathrm{~mm}$ in thickness. The coil was connected to the tube combined with a 0.46-mm internal diameter silastic tubing (Dow Corning Corp., Midland, MI, USA) and a 23 G scalp vein set. Cold water $\left(4{ }^{\circ} \mathrm{C}\right)$ was perfused from the homoeothermic device, and the water circulation was controlled by a




peristaltic pump. In order to allow animals to move freely, the water was infused through a stainless swivel (Instech Laboratories, Inc., Plymouth Meeting, PA, USA). The cooling device was surgically placed into a space between the temporalis muscle and the left side of the skull. Local cooling was estimated by measuring brain temperature after implanting the sterilized metal probe through a guide cannula. Ipsilateral brain temperature was locally maintained at $33^{\circ} \mathrm{C}$ for 66 to 78 hours (data not shown), while the temperature in the contralateral side was maintained at normal body temperature. The device and guide cannula were well cemented carefully.

\section{Focal stab injury and hypothermic strategies}

To investigate the effect of hypothermia on microglial migration in vivo, focal stab injury was given by locating a $26 \mathrm{G}$ needle in the cortical area of the brain through $22 \mathrm{G}$ guide cannula at $-2 \mathrm{~mm}$ below the dura mater. Hypothermia $\left(33^{\circ} \mathrm{C}\right)$ using cold water circulation was initiated either at six hours before or after focal stab injury and maintained for 72 hours. The needles were kept in place for five minutes and then removed. The guide cannula was covered with paraffin, and the animals were returned to their cages before sacrifice after 72 hours.

\section{Microglia immunohistochemistry}

Rats were anesthetized with diethyl ether and perfused with $4 \%$ paraformaldehyde (PFA) diluted in 0.1 M PBS after transcardial perfusion with cold saline. Brains were post-fixed by using $4 \%$ PFA for three days, and then cryo-protected with $30 \%$ sucrose solution for three days. Three animals were used for each experimental group. The fixed brains were embedded in optimal cutting

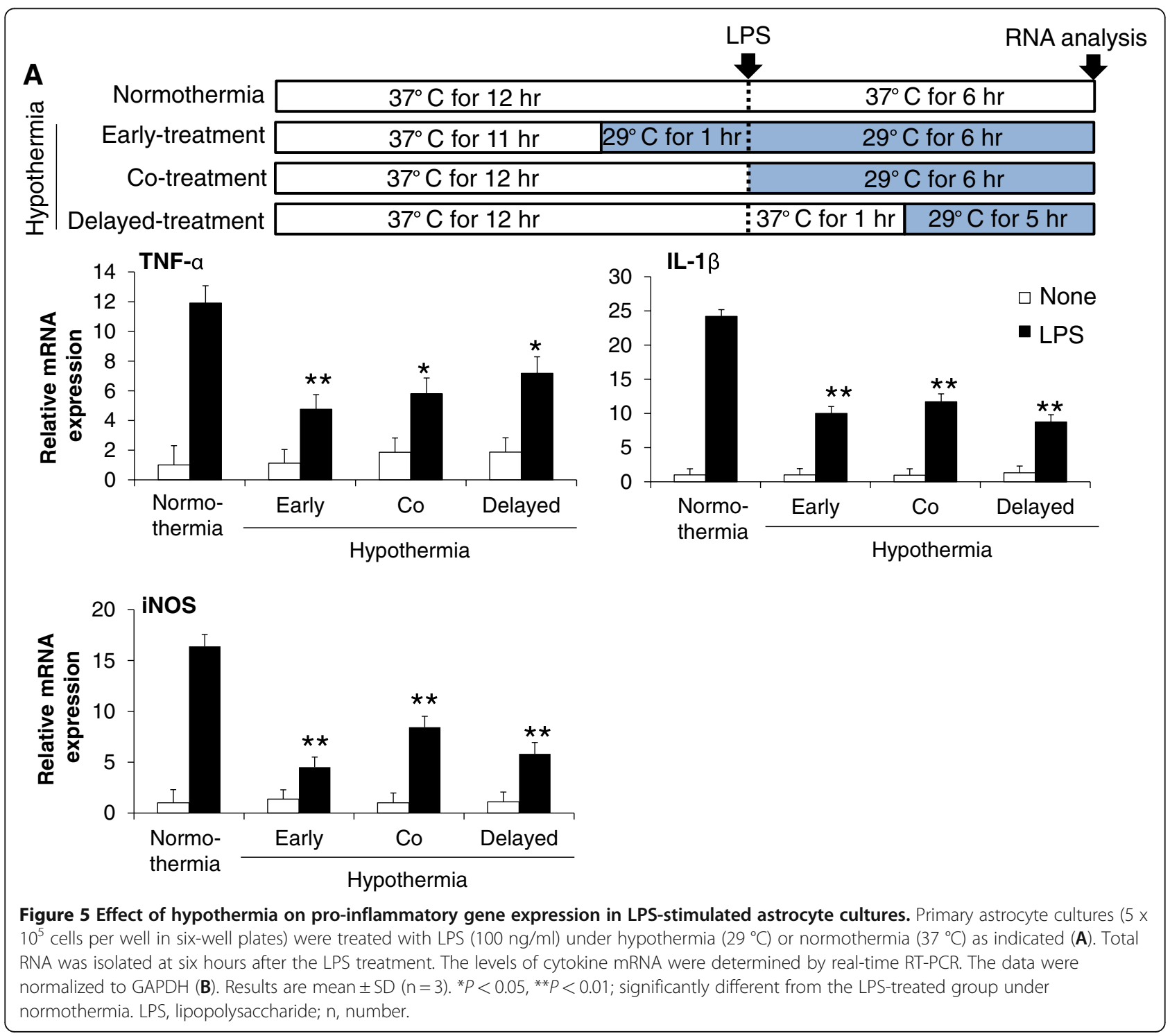


temperature (OCT) compound (Tissue-Tek, Sakura Finetek, Japan) for frozen section and then cut into 12$\mu \mathrm{m}$-thick horizontal sections. For immunohistochemistry, the sections were washed briefly and blocked with $1 \% \mathrm{BSA}$ and $5 \%$ normal donkey serum. After washing with PBS, the sections were incubated at $4{ }^{\circ} \mathrm{C}$ overnight with the rabbit polyclonal anti-Iba- 1 antibody (1:500 dilution; WAKO, Japan). The sections were then incubated with donkey FITC- or Cy3-conjugated anti-rabbit IgG antibody (1:200 dilution; Jackson Immunoresearch Laboratories; West Grove, PA, USA). The sections were mounted on 4',6-diamidino-2-phenylindole (DAPI)-containing gelatin solution. Data acquisition and immunohistological intensity measurement of Iba-1 staining was performed with a NIH image J program (NIH Image; Bethesda, MD, USA) as described previously [33]. In brief, tiled images of each section were captured with a CCD color video camera (Olympus D70). A composite of the images $(4000 \times 3000$ pixels each; 1 pixel $=2.5 \mu \mathrm{m} x$ $2.5 \mu \mathrm{m})$ was then constructed for each section with Photoshop CS3 version. The images were binary thresholded at $50 \%$ of the background level, and the particles were then converted to a sub-threshold image area with a size less than 300 and larger than 5 pixels, which was judged as Iba- 1 positive cells. To count the Iba- 1 positive cells, three concentric circles were placed in the periregion of the injury site in the sub-threshold image of the six independent sections. The cells in the three circles were counted and statistically analyzed.

\section{5-Bromo-2'-deoxyuridine assay}

5-Bromo-2'-deoxyuridine (BrdU, $200 \mathrm{mg} / \mathrm{kg}$, Sigma) was administered intraperitoneally. The rats were sacrificed at three days after the BrdU injection. The brain tissues were horizontally sliced and prepared for immunohistochemistry as described above. Then, DNA denaturation

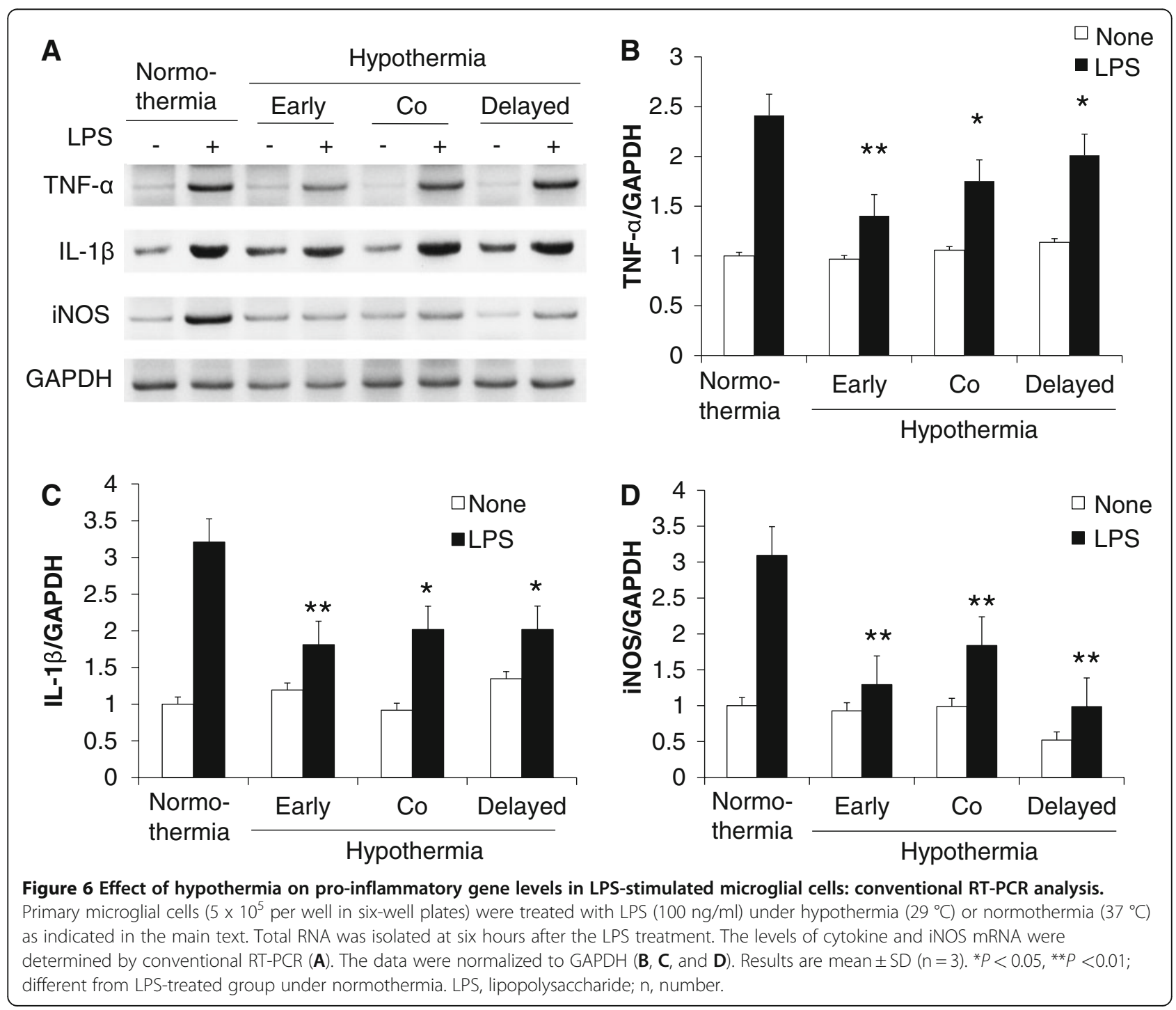


was performed by incubating with $1 \mathrm{M} \mathrm{HCl}$ for $30 \mathrm{~min}$ utes at $25{ }^{\circ} \mathrm{C}$. The tissues were sequentially incubated with rat monoclonal anti-BrdU antibody (1:200, Serotec, Kidlington, UK) and FITC-conjugated anti-rat IgG antibody (1:200).

\section{Statistical analysis}

Statistical comparisons between different treatments were done by either a Student's $t$ - test or one-way ANOVA with Dunnett's multiple-comparison tests with the SPSS program (version 14.0 K) (SPSS Inc., Chicago, IL). Differences with a value of $P<0.05$ were considered to be statistically significant.

\section{Results}

Inhibitory effect of hypothermia on microglial NO production

To examine the effect of hypothermic conditions on NO synthesis in activated microglia cells, BV-2 mouse microglial cells were treated with TLR4 ligand LPS $(100 \mathrm{ng} / \mathrm{ml})$ under normothermic $\left(37^{\circ} \mathrm{C}\right)$ or hypothermic conditions $\left(33{ }^{\circ} \mathrm{C}, 29^{\circ} \mathrm{C}\right.$ ) for 0 to 48 hours, and nitrite production was measured. Hypothermic conditions led to a decrease in NO production in LPS-activated BV-2 microglial cells compared to normothermia (Figure 1A). The effect of $29^{\circ} \mathrm{C}$ was greater than that of $33^{\circ} \mathrm{C}$. The inhibitory effect of hypothermia was similarly observed in primary microglial cells (Figure 1B) and primary astrocyte cultures (Figure 1C). The hypothermic condition did not significantly affect cell viability of either BV-2 microglial cells, primary microglial cells, or primary astrocyte cultures (Figure 1).

Time-dependent effects of hypothermia on microglial NO production

To determine the time-dependent effect of hypothermia, hypothermic exposure was initiated at different time points before or after LPS stimulation in BV-2 microglial cells (Figure 2A). BV-2 microglial cells were exposed to hypothermia $\left(33{ }^{\circ} \mathrm{C}, 29{ }^{\circ} \mathrm{C}\right)$ three hours prior to LPS treatment or 0 to 12 hours after LPS stimulation, and NO production was assessed at the time point indicated. The results showed that all of the hypothermic treatments decreased NO production significantly, and the

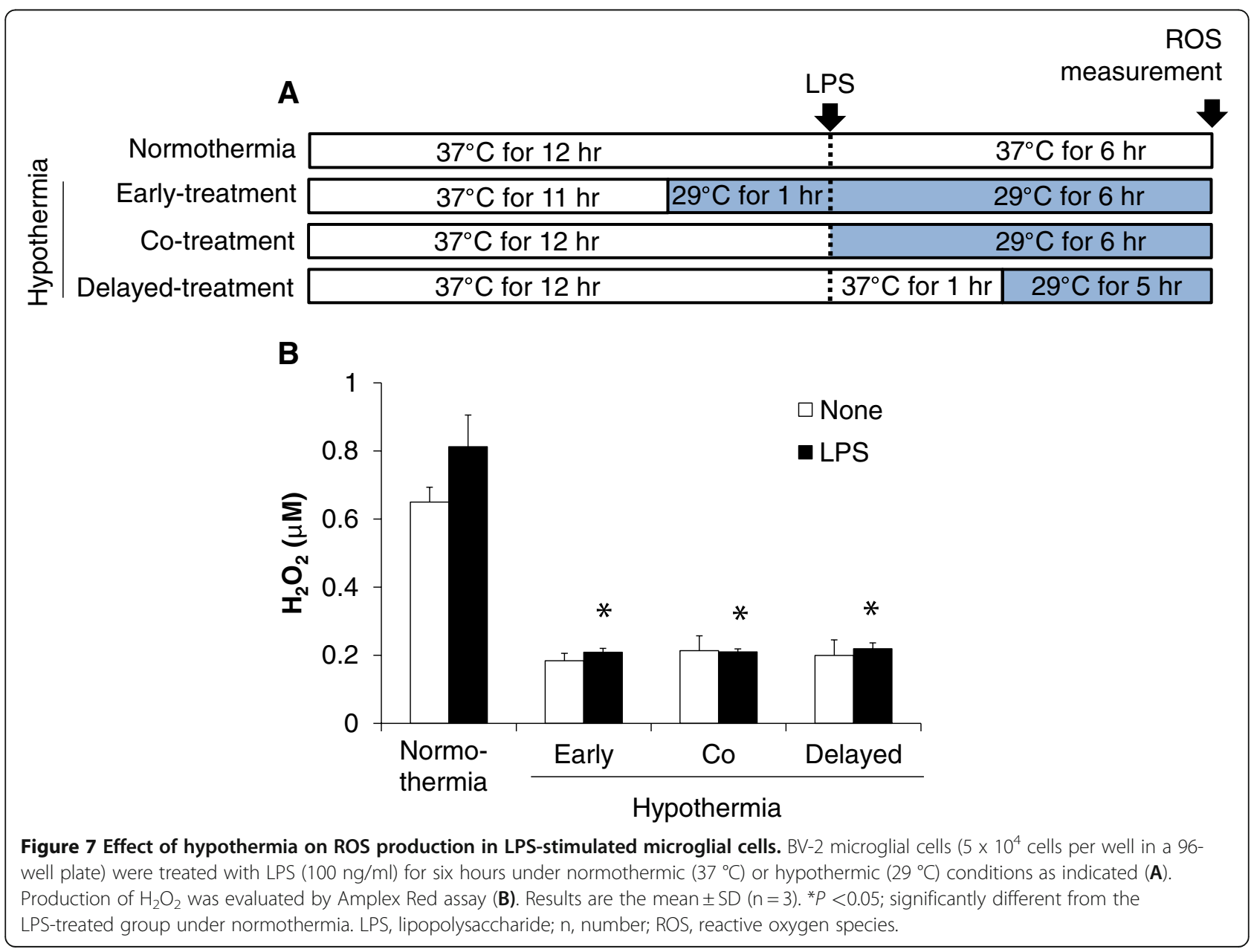


early-treatment showed the greatest effects (Figure 2B). The effect of $29{ }^{\circ} \mathrm{C}$ was again greater than that of $33{ }^{\circ} \mathrm{C}$. When the initiation of hypothermia was delayed to 3 to 12 hours after LPS stimulation, the inhibitory effect was still significant. Cell viability was not significantly affected by those treatments (Figure 2C). Based on these results, further hypothermic experiments were done at $29^{\circ} \mathrm{C}$. In these experiments (Figure 2), however, both the initiation and the duration of hypothermia were different among the experimental groups. Thus, in the next set of experiments, the duration of hypothermia was fixed to six hours with different initiation schedules (Figure 3A). Hypothermia initiated six hours prior to LPS stimulation or 0 to 6 hours after LPS stimulation (conditions 1, 2, 3, and 4) efficiently inhibited microglial NO production. However, the effect of hypothermia delayed to 12 to 18 hours after LPS stimulation (conditions 5 and 6) was greatly reduced. Hypothermia for six hours duration seems to be required for the optimal inhibitory effects, since a three hour duration initiated at the same time point showed less effect (conditions 4 versus 7 ). There was no significant difference in cell viability under any of these conditions (Figure $3 \mathrm{C}$ ). The results suggest that therapeutic hypothermia initiated even three to six hours after brain injury may have anti-microglia activity.

\section{Hypothermia inhibition of proinflammatory cytokine/} chemokine expression and ROS production in microglia Having shown that hypothermia inhibits microglial NO production, we next determined whether hypothermia blocks microglial expression of proinflammatory cytokines, chemokines, or iNOS by Real-Time quantitative PCR (Figure 4). Early-, co-, or delayed-hypothermia attenuated with varying magnitudes the LPS-induced expression of TNF- $\alpha$, IL-1 $\beta$, iNOS, IL-6, IL-12, CXCL10, CCL4, and CCL20 in primary microglia cultures. It should be noted that delayed hypothermia was effective in inhibiting the expression of all proinflammatory genes examined. Anti-inflammatory cytokine IL-10 expression, however, was not significantly influenced by either LPS or hypothermia. Hypothermia inhibited astrocytic expression of proinflammatory mediators in a similar fashion (Figure 5). Hypothermia inhibition of the inflammatory gene expressions in microglial cells was similarly observed in conventional RT-PCR (Figure 6). LPS-stimulated microglial cells are known to produce 
reactive oxygen species (ROS). Measurements of ROS using Amplex Red (Figure 7) or DCFDA (Figure 8) revealed that hypothermia reduced microglial ROS production. Early-, co-, or delayed-hypothermia similarly reduced ROS production in microglial cells. We next employed a hypoxia model to further evaluate the effect of hypothermia on microglial activation. Hypoxia led to microglial activation as determined by iNOS induction, which was attenuated under hypothermic conditions (Figure 9). Early-treatment was most effective in inhibiting iNOS induction. These results indicate that hypothermia attenuates the inflammatory activation of microglia following LPS or hypoxic stimulation.

\section{The protective effect of hypothermia against microglial} neurotoxicity

The effect of hypothermia on microglial neurotoxicity was evaluated using co-cultures of microglia and neurons. First of all, co-cultures of BV-2 microglial cells and B35-EGFP neuroblastoma cells were utilized to evaluate microglial neurotoxicity (Figure 10). In these co-cultures, LPSstimulated microglia exhibited cytotoxic effects on the neuroblastoma cells. At the end of co-culturing, EGFPpositive viable neuroblastoma cells were counted to measure the microglial cytotoxicity toward the co-cultured neuroblastoma cells. Hypothermia given before, during, or after LPS stimulation of the microglia attenuated the microglial neurotoxicity in the co-cultures. The protective effect of hypothermia against microglial neurotoxicity was similarly observed at $33^{\circ} \mathrm{C}$ and $29^{\circ} \mathrm{C}$, as well as in the co-cultures of primary microglia/neuroblastoma cells (Figure 11). The effect of hypothermia on microglial neurotoxicity was also examined in the co-cultures of primary microglia and primary cortical neurons using a culture insert (Figure 12). Primary microglia cultures were seeded in the culture insert, while primary cortical neurons were cultured in the lower compartment. Early-, co-, or delayed-treatment of hypothermia protected neurons

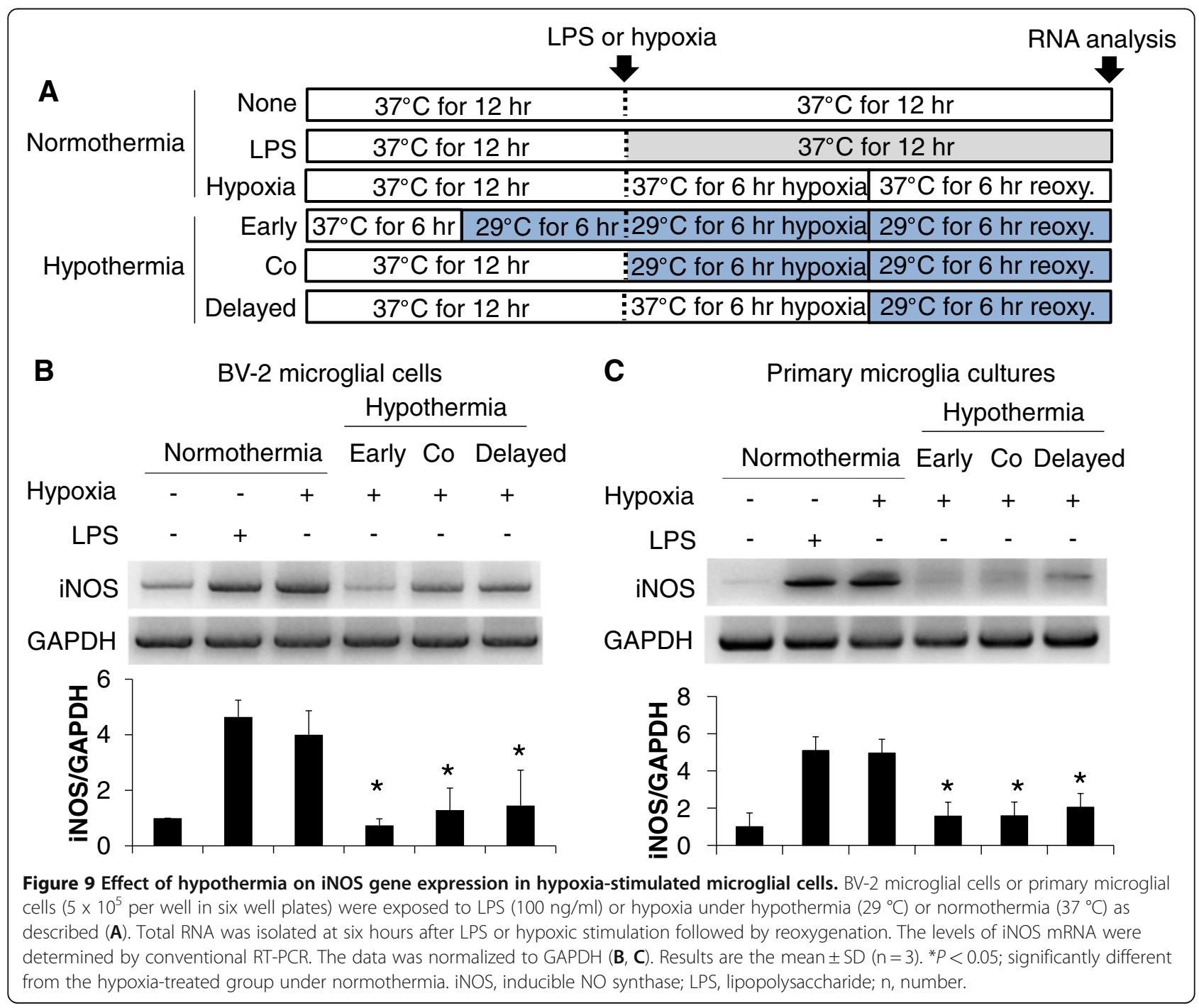


from microglial toxicity with different magnitudes, with early treatment being most effective. Similar levels of protection were seen when conditioned media of microglia cultures were added to cortical neuron cultures (Figure 13). The direct neuroprotective effect of hypothermia was next examined by exposing B35-EGFP neuroblastoma cells to $\mathrm{H}_{2} \mathrm{O}_{2}$ or NO donor SNP under hypothermic conditions (Figure 14). Hypothermic conditions $\left(33^{\circ} \mathrm{C}\right.$ or $29^{\circ} \mathrm{C}$ ) partly protected the neuroblastoma cells against $\mathrm{H}_{2} \mathrm{O}_{2}$ or SNP toxicity. These results indicate that the neuroprotective effects of hypothermia are achieved by inhibiting neurotoxic microglial activation as well as by reducing direct neurotoxicity of oxidative or nitrosative stress.

\section{The inhibitory effect of hypothermia on microglial cell migration}

It has been previously shown that microglial cell migration is one of the main components of brain responses to injury

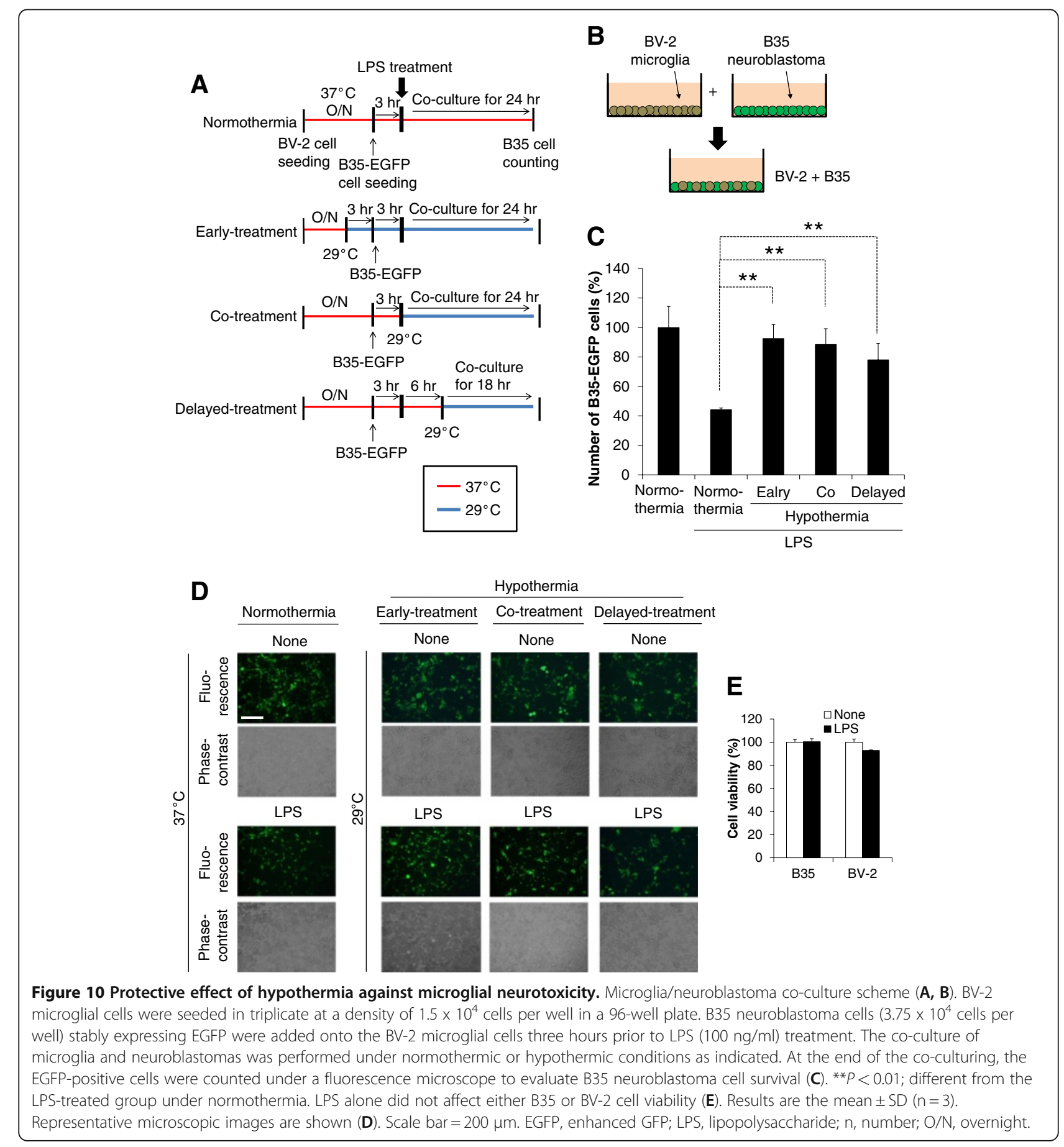


and inflammation [45]. The effect of hypothermia on microglial cell migration was determined by two different cell migration assays. In the Boyden chamber assay, the migration of BV-2 microglial cells or primary microglial cells across a membrane was diminished by hypothermic conditions $\left(33{ }^{\circ} \mathrm{C}\right.$ or $\left.29{ }^{\circ} \mathrm{C}\right)$ compared to normothermia (Figure 15). The migration-inhibiting effects of hypothermia were greater at $29{ }^{\circ} \mathrm{C}$ than at $33{ }^{\circ} \mathrm{C}$. Similar effects of hypothermia $\left(29^{\circ} \mathrm{C}\right)$ were observed in the wound healing assay (Figure 16). After the BV-2 microglial cells were
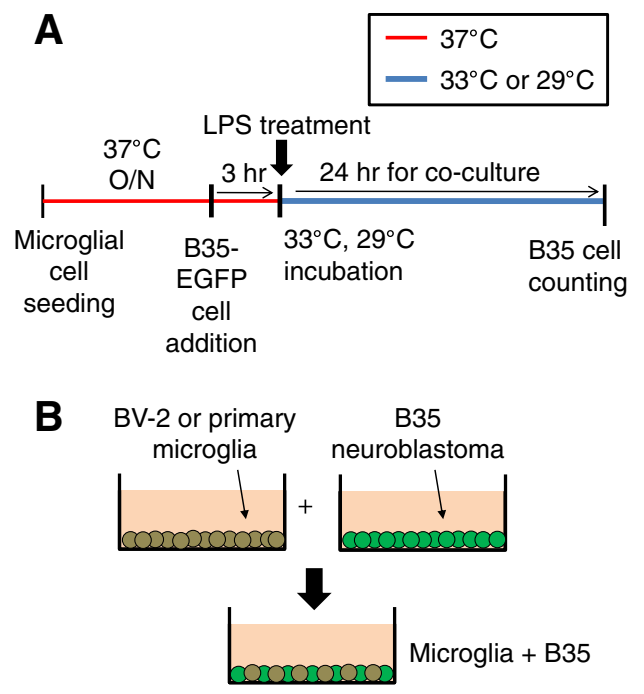
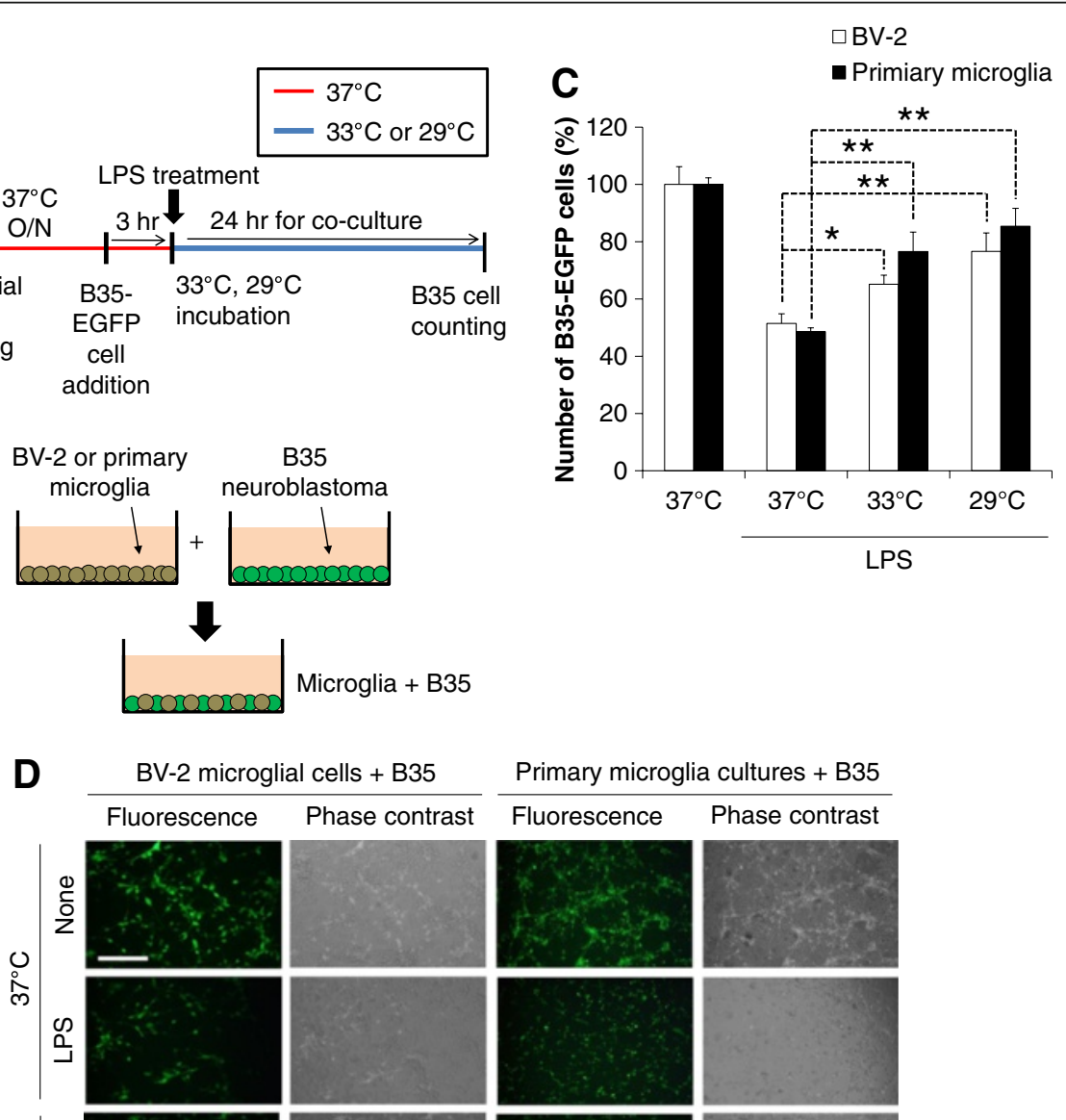

\begin{tabular}{l} 
Primary microglia cultures + B35 \\
\hline Fluorescence Phase contrast
\end{tabular}
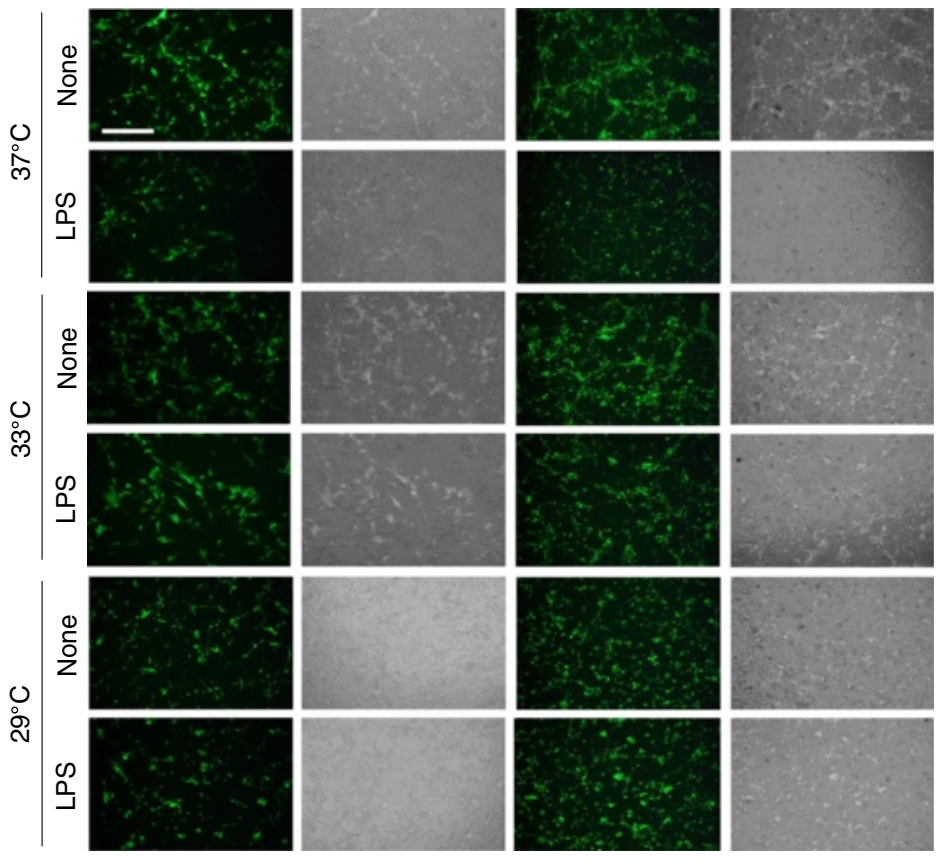

Figure 11 Protective effect of hypothermia against microglial neurotoxicity: co-cultures of primary microglia and neuroblastoma cells. B35-EGFP neuroblastoma cells were added onto BV-2 microglial cells or primary microglia cultures three hours prior to LPS (100 ng/ml) treatment. The co-culture of microglia and neuroblastoma was performed under normothermia $\left(37^{\circ} \mathrm{C}\right)$ or hypothermia $\left(33^{\circ} \mathrm{C}, 29^{\circ} \mathrm{C}\right)$ as indicated $(\mathbf{A}, \mathbf{B})$. At the end of the co-culture, the EGFP-positive cells were counted under fluorescence microscope to evaluate B35 neuroblastoma cell survival (C). Results are mean $\pm S D(n=3)$. ${ }^{*} P<0.05,{ }^{* *} P<0.01$; different from LPS-treated group under normothermia. LPS alone did not affect B35 cell viability (data not shown). Representative microscopic images are also shown (D). Scale bar $=200 \mu \mathrm{m}$. EGFP, enhanced GFP; LPS, lipopolysaccharide; n, number; O/N, overnight. 

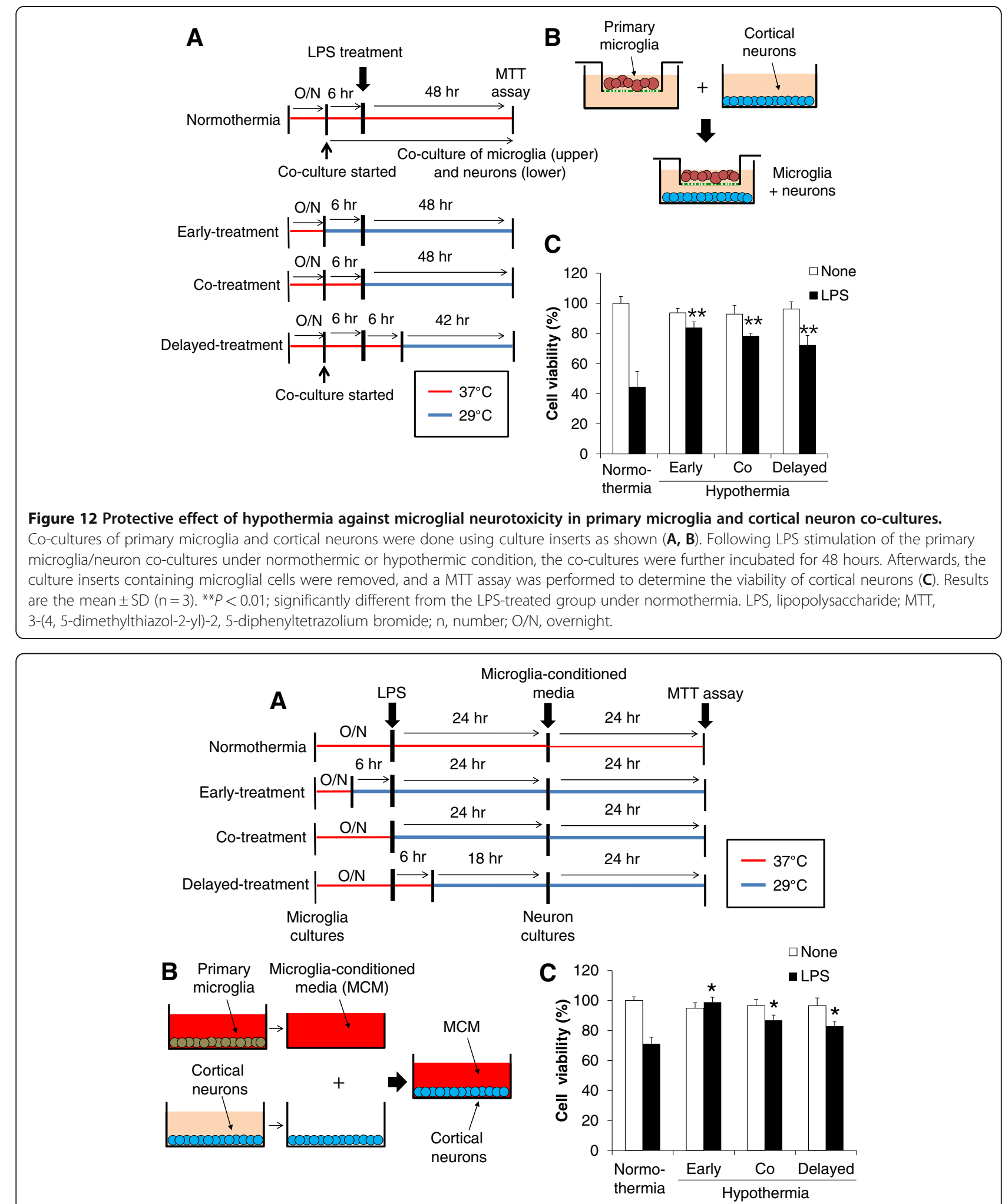

Figure 13 Protective effect of hypothermia against neurotoxicity of microglia-conditioned media. Microglia-conditioned media (MCM) were collected after stimulation of primary microglia cultures with LPS under normothermic or hypothermic condition as indicated (A, B). MCM were added to primary cortical neurons and the viability was assessed by a MTT assay 24 hours later $(\mathbf{C})$. Results are mean $\pm S D(n=3)$. ${ }^{*} P<0.05$; different from LPS-treated group under normothermia. LPS, lipopolysaccharide; MTT, 3-(4, 5-dimethylthiazol-2-yl)-2, 5-diphenyltetrazolium bromide; n, number; O/N, overnight. 

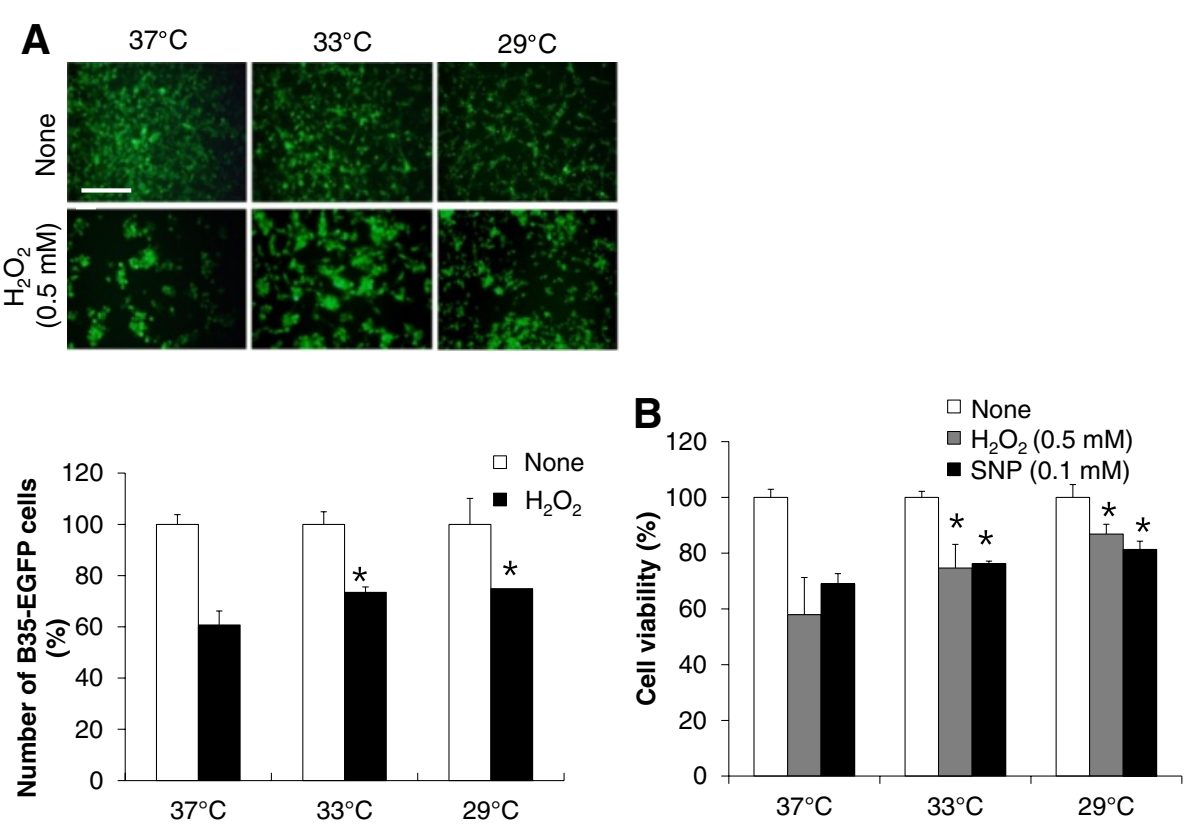

Figure 14 Neuroprotective effect of hypothermia against oxidative or nitrosative stress. B35-EGFP neuroblastoma cells were seeded in triplicate at a density of $5 \times 10^{4}$ cells per well in 96-well plate, and then treated with $\mathrm{H}_{2} \mathrm{O}_{2}(0.5 \mathrm{mM})$ or SNP $(0.1 \mathrm{mM})$ under normothermic $\left(37^{\circ} \mathrm{C}\right)$ or hypothermic $\left(33^{\circ} \mathrm{C}\right.$ or $29^{\circ} \mathrm{C}$ ) conditions for 24 hours. After incubation B35-EGFP cells were counted (A, lower) or subjected to a MTT assay (B) for assessment of cell viability. Representative images of the fluorescence microscopy are shown $(\mathbf{A}$, upper). Scale bar $=200 \mu \mathrm{m}$. Results are the mean $\pm \mathrm{SD}(\mathrm{n}=3) .{ }^{*} P<0.05$; significantly different from $\mathrm{H}_{2} \mathrm{O}_{2}$ - or SNP-treated group under normothermia. EGFP, enhanced GFP; LPS, lipopolysaccharide; MTT, 3-(4, 5-dimethylthiazol-2-yl)-2, 5-diphenyltetrazolium bromide; n, number; SNP, sodium nitroprusside.
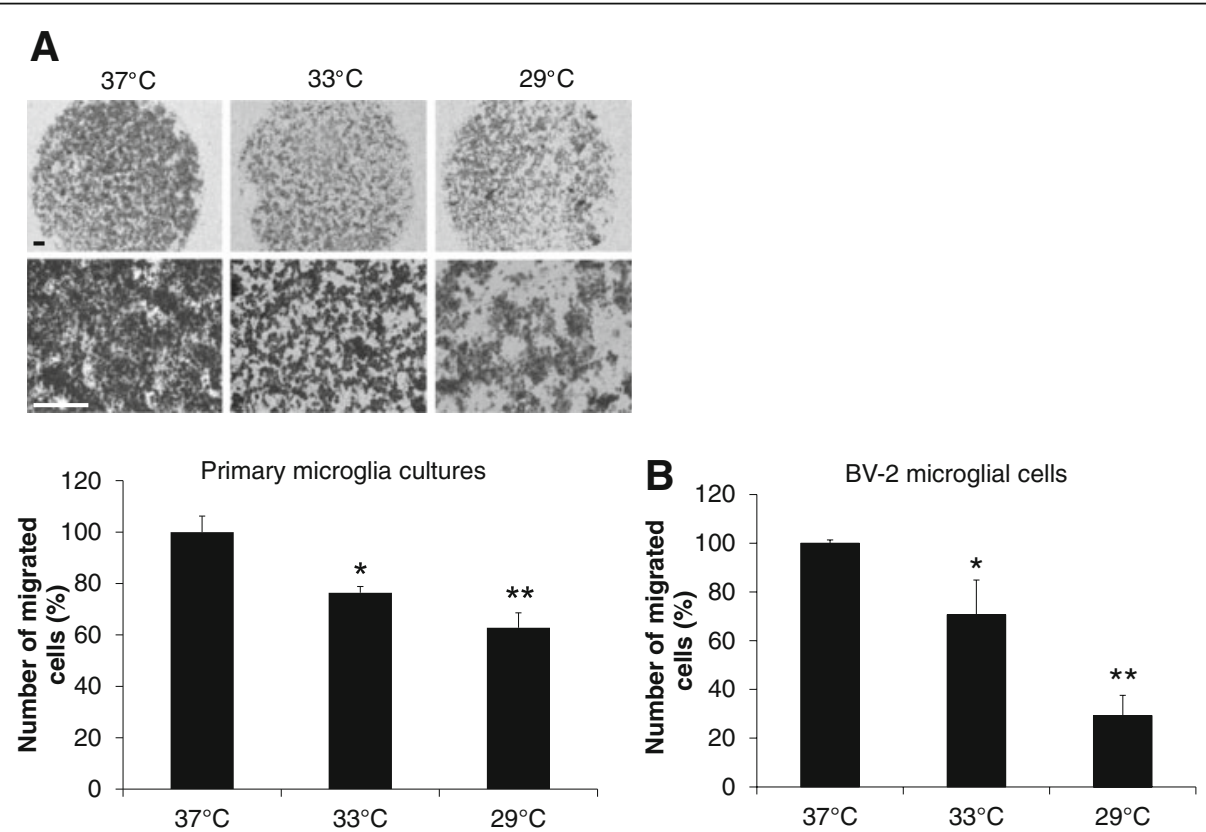

Figure 15 Effect of hypothermia on microglial cell migration: the Boyden chamber assay. Primary microglial cultures (A) or BV-2 microglial cells $\left(1 \times 10^{4}\right.$ cells per well) $(\mathbf{B})$ were seeded on the upper compartment of the Boyden chamber. After three hours (BV-2 microglial cells) or six hours (primary microglia) incubation under normothermic $\left(37^{\circ} \mathrm{C}\right)$ or hypothermic $(33 \mathrm{C}, 29 \mathrm{C})$ conditions, cells that migrated through the membrane were stained (A upper) and counted to evaluate the relative cell migration (A lower, B). A representative microscopic image for each condition is shown (magnification, $x 40$ or $\times 200)$ (A upper). Scale bar $=200 \mu$ m. Results are the mean \pm SD $(n=3)$. ${ }^{* *} P<0.01,{ }^{*} P<0.05 ;$ significantly different from normothermia (37 C). n, number. 
exposed to hypothermia before or after the scratch wound, microglial cell migration was assessed by measuring wound closure at the end of a 24 to 48 hour incubation period. Early-, co-, and delayed-treatment of hypothermia suppressed the wound closure to different degrees. No significant difference in cell proliferation was observed between normothermia and hypothermia conditions during this time period (data not shown). Delayed hypothermia effectively inhibited microglial migration, albeit to a lesser degree than that of early- or cotreatment. These results indicate that delayed hypothermia may reduce microglial migration in inflammatory brain. In the next set of experiments, the effect of hypothermia on microglial migration was examined in vivo using a rat model of stab injury (Figure 17). Local hypothermia $\left(33{ }^{\circ} \mathrm{C}\right)$ was applied to rat brain using a cooling coil before, during, or after a needle injury in the cortex, and then migration of microglia toward the injury site was evaluated by immunohistochemical staining of Iba-1, a microglia-specific marker. Immunohistochemical image analysis of horizontal sections revealed that local hypothermia significantly inhibited microglial migration toward the injury site. Relative migration of microglia was based on the number of cells present in the three concentric circles (Figure 17C). Proliferation of microglia was minimal around the injury site as determined by BrdU staining (Figure 18), indicating that the increase in the number of microglia around the injury site was mostly due to migration rather than proliferation of microglia. A similar result was obtained from PCNA staining (data not shown). RNA analysis of cortical tissue indicated that local hypothermia also attenuated the injury-induced expression of proinflammatory cytokines such as TNF- $\alpha$ and IL-1 $\beta$ and iNOS (Figure 19), corroborating the earlier findings on the anti-inflammatory effects of hypothermia in vivo.

\section{Discussion}

In this study, we report that hypothermia reduces microglial activation in a cooling time-dependent manner. Hypothermia attenuated several phenotypes of microglia that are associated with neuroinflammation: 1) hypothermia inhibited microglial production of NO, ROS, and proinflammatory cytokines/chemokines following TLR4 or hypoxic stimulation; 2) it attenuated microglial neurotoxicity; and 3) it reduced microglial migration toward the injury site. More importantly, hypothermia initiated after stimulation of the microglia (with either
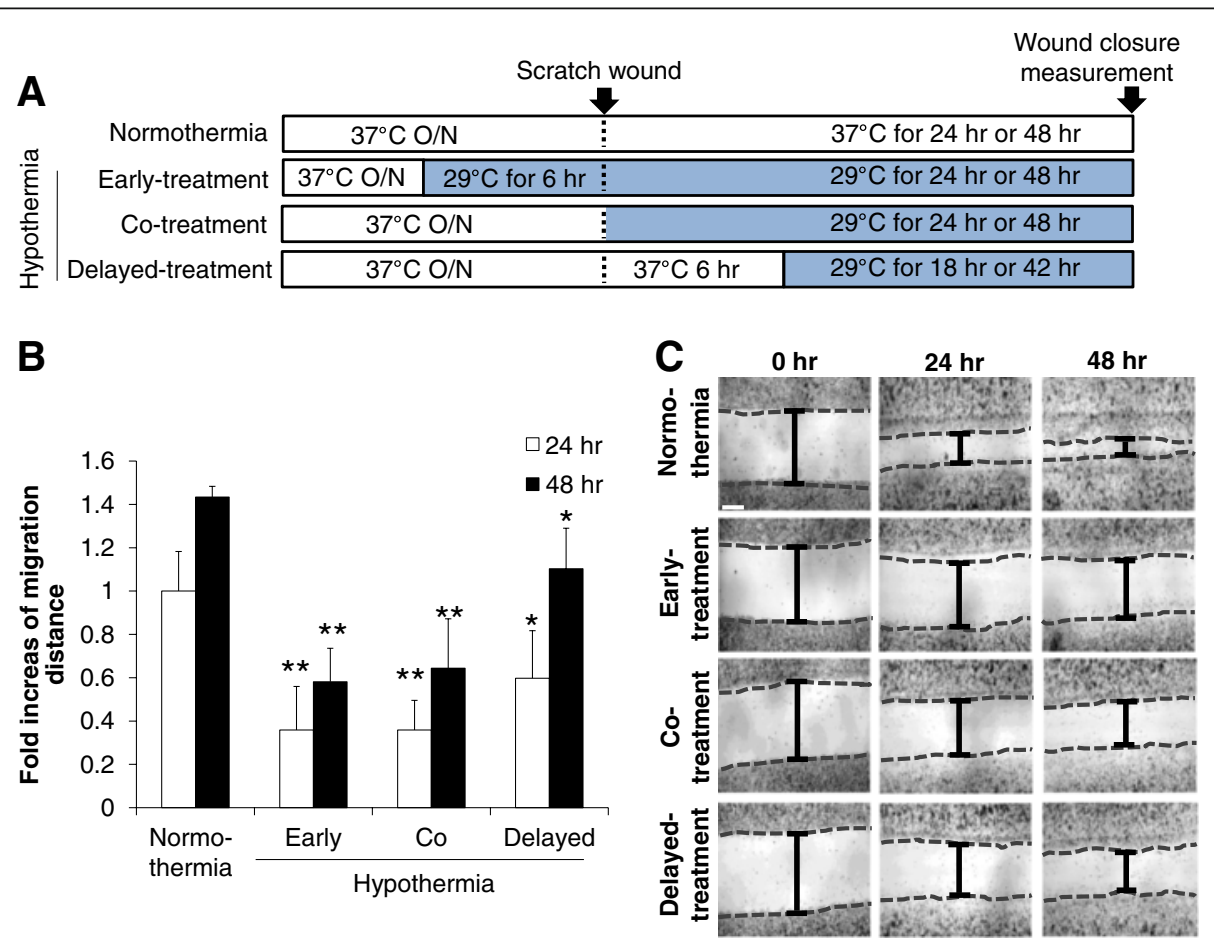

Figure 16 Effect of hypothermia on microglial cell migration: wound healing assay. Effect of hypothermia on microglial cell migration was investigated by the wound healing assay. When the cells reached $90 \%$ confluence, a single wound was made in the center of the cell monolayer and cell debris was removed by washing with PBS. After 24 hours or 48 hours of incubation under normothermic or hypothermic condition as indicated $(\mathbf{A})$, the wound closure areas were visualized under an inverted microscope and quantified (B). Results are the mean \pm SD $(\mathrm{n}=3) .{ }^{*} P<0.05,{ }^{*} P<0.01$; different from normothermia $\left(37^{\circ} \mathrm{C}\right)$ at the same time point. A representative microscopic image for each condition is shown (magnification, $\times 100)($ C). Scale bar $=200 \mu \mathrm{m}$. n, number; O/N, overnight. 

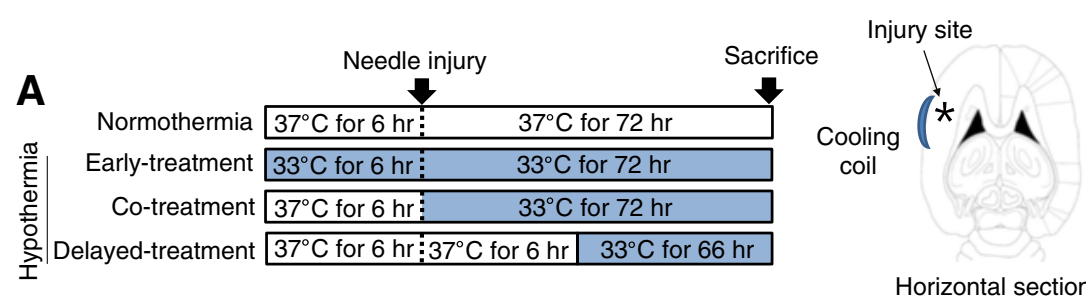

B

Hypothermia
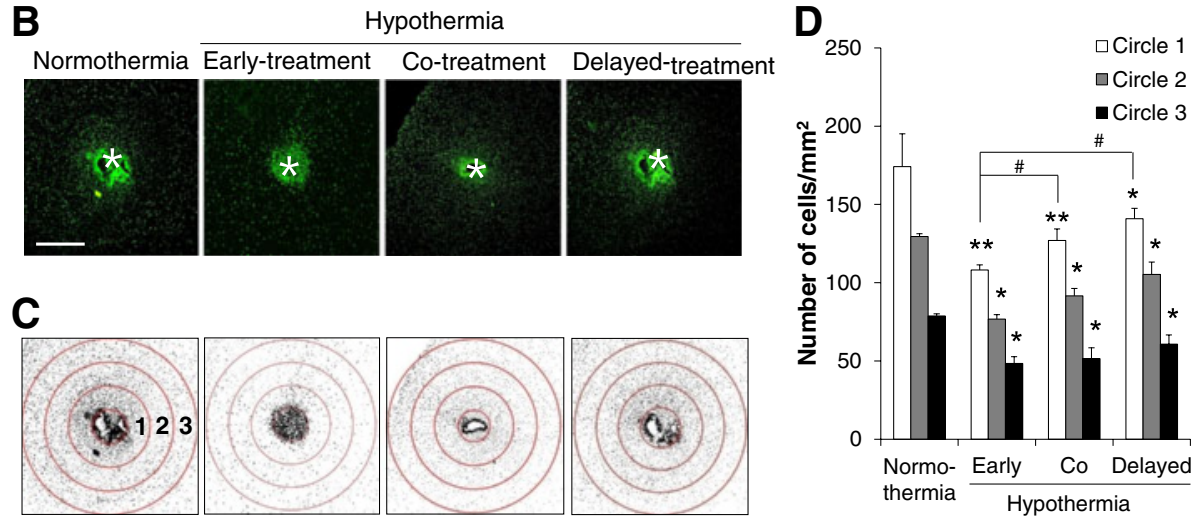

Figure 17 Effect of hypothermia on microglial migration in vivo. To assess the effect of therapeutic hypothermia on microglial migration in vivo, focal stab injury was created by placing a needle in the cortical area of the brain through a guide cannula. Local hypothermia $\left(33^{\circ} \mathrm{C}\right.$ ) using cold water circulation through a cooling coil was initiated either six hours before or after the needle injury, and maintained for 66 to 78 hours as indicated (A). Asterisks indicate the injury site. Horizontal sections of rat brain were subjected to microglial immunohistochemistry (Iba-1, green) (B). A representative microscopic image for each condition is shown (magnification, $x 40$ ). Scale bar $=1 \mathrm{~mm}$. Data acquisition and immunohistological intensity measurement of Iba-1 staining was performed with a NIH image J program (C). To count the Iba-1 positive cells, three concentric circles with constant interval were placed in the peri-region of the injury site (asterisk) in the sub-threshold image of the six independent sections. Three animals were used for each experimental group. The cells in the three circles were counted and statistically analyzed (D). Results are the mean $\pm S D$. ${ }^{*} P<0.05,{ }^{* *} P<0.01$; different from the same circle under normothermia $\left(37^{\circ} \mathrm{C}\right)$. $\# P<0.05$; different from the two conditions indicated.

LPS or hypoxia) was also able to inhibit inflammatory activation of microglia, and the inhibitory effects of hypothermia were initiation and duration time-dependent. This was demonstrated in the microglial production of inflammatory mediators, microglial neurotoxicity, and microglial migration. In general, the microglia-inhibiting effects of hypothermia were greater at $29^{\circ} \mathrm{C}$ than at $33^{\circ} \mathrm{C}$, although the differences between the two temperatures seemed small in some cases.

Our data suggest that post-injury hypothermia may effectively suppress deleterious microglial activation and subsequent neuroinflammation. Our observation that hypothermic exposure given after microglial stimulation is effective in attenuating inflammatory activation of microglia has important clinical implications, since the therapeutic hypothermia is usually delivered to patients after brain damages, such as ischemic stroke and traumatic brain injury, to improve neurological outcomes as one of the neuroprotective strategies [46]. We have also demonstrated using cultured microglial cells as an in vitro model that hypothermia initiated three hours after inflammatory stimulation (six hours duration) most strongly inhibited microglial NO production among the different co- or delayed hypothermic conditions: in fact, it was as effective as hypothermia initiated before inflammatory stimulation (pre-LPS hypothermia) (Figure 3). These results may help determine the optimal time window for post-injury hypothermic therapy. It was previously reported that hypothermic preconditioning prior to injury was effective through tolerance induction in a mouse model $[47,48]$. In the present study, pretreatment by hypothermia also showed superior effects in general including reduction in microglial NO/TNF- $\alpha$ production, neurotoxicity, and cell migration. These results may be attributed to the preconditioning effects or the longer duration of the hypothermia treatment [27,49-51]. Our data indicate that hypothermia initiated six hours after LPS stimulation efficiently inhibited microglial nitrite production. In the report by Ohta et $a l$., the therapeutic time window of hypothermia lasted for four hours after reperfusion in a middle cerebral artery occlusion (MCAO) model [52]. Hypothermia was effective when initiated 30 minutes to three hours after occlusion/ reperfusion in the MCAO model in other studies [53-62]. This indicates that the maximum therapeutic time window of hypothermia may be four to six hours after injury. Our results showed that LPS-induced pro-inflammatory cytokine mRNA levels were downregulated by hypothermia in microglial cells, which is consistent with 

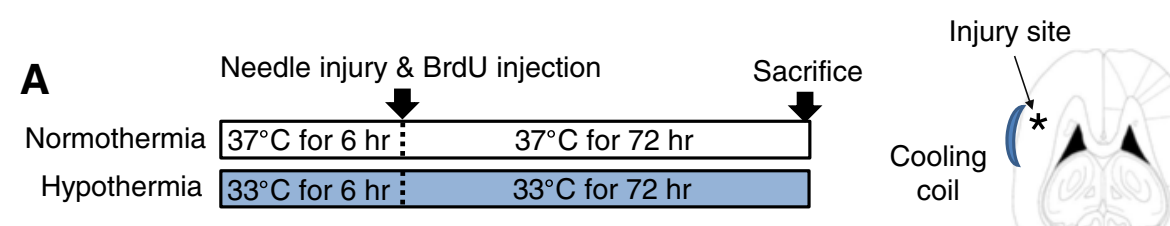

B

Iba-1
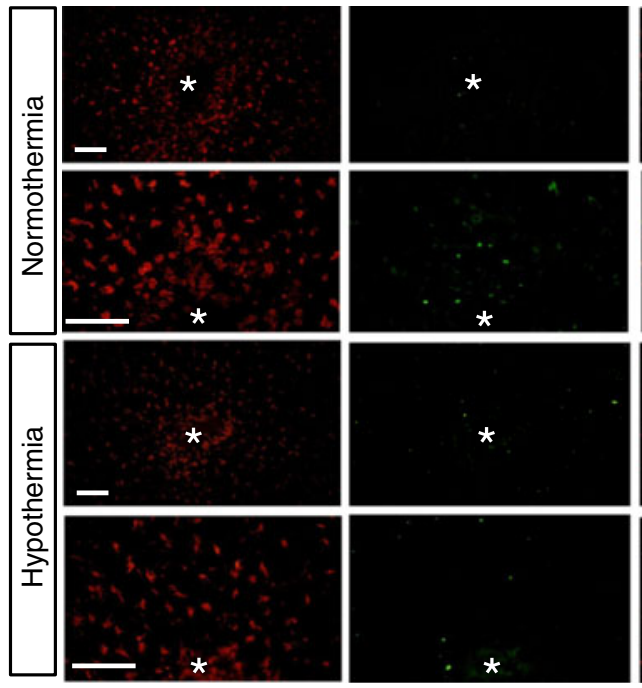
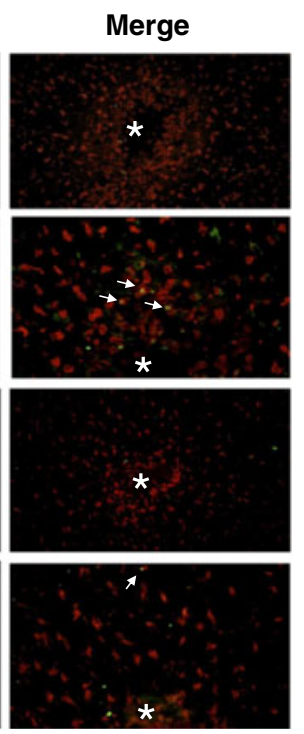

Figure 18 Effects of local hypothermia on microglial proliferation in vivo. A focal needle injury and BrdU injection (i.p., $200 \mathrm{mg} / \mathrm{kg}$ ) were done under normothermic or hypothermic condition as indicated (A). Iba-1 (red) or BrdU (green) immunochemistry was done to determine the effects of local hypothermia on microglial proliferation in vivo (B). Asterisks indicate the injury site. Arrows indicate Iba-1 and BrdU double positive cells in the merged images. A representative microscopic image for each condition is shown (magnification, $x 200$ or $x 400$ ). Scale bar $=200 \mu \mathrm{m}$. BrdU, 5-bromo-2'-deoxyuridine; i.p., intraperitoneally.

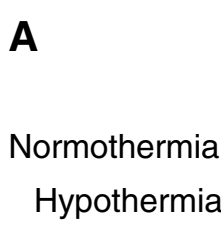

B

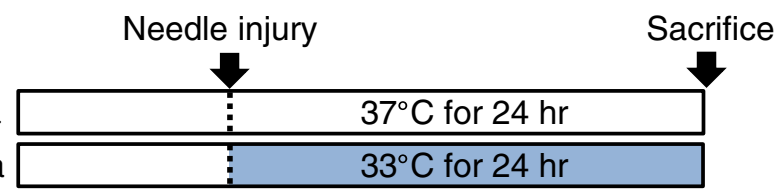

Injury

Normo- Hypo-

Sham thermia thermia

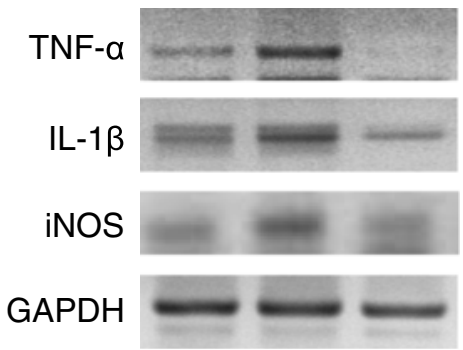

Figure 19 Inhibition of proinflammatory cytokine and iNOS expression by local hypothermia in the rat model of stab injury. After the focal stab injury in the cortex under normothermia or hypothermia as described in the main text $(\mathbf{A})$, cortical tissues were prepared and subjected to RT-PCR analysis (B). Compared to normothermia, hypothermia diminished the injury-induced expression of TNF-a, IL-1 13 , and iNOS. iNOS, inducible NO synthase. 
previous studies $[15,18,20,38,63]$. Lowering the temperature decreased p38 MAPK activation and the subsequent p38-regulated production of proinflammatory cytokines and NO in ATP-activated microglia [17], suggesting that the suppression of p38 is one of the possible mechanisms of hypothermic attenuation of proinflammatory gene expression in microglia. Although delayed hypothermia suppressed cytokine mRNA expression more effectively than co-treatment, TNF- $\alpha$ showed a different mRNA expression pattern from the others (Figure 4). The differential effects of hypothermia on the expression of TNF- $\alpha$ and other proinflammatory mediators were also observed in the conventional RT-PCR analysis (Figure 6) and in previous reports that used a variety of experimental models $[18,64,65]$. It is well documented that the gene expression of TNF- $\alpha$ is regulated at the post-transcriptional level, such as mRNA stability [66-68]. Measurement of TNF- $\alpha$ and other cytokines at the protein level should be done in future studies to further understand the differential effects of hypothermia. There was no difference between early-, co-, and delayed-hypothermia on the production of $\mathrm{H}_{2} \mathrm{O}_{2}$ (Figure 7). While the Amplex Red assay primarily detects $\mathrm{H}_{2} \mathrm{O}_{2}$ released from the cells, the cell permeant fluorogenic dye, DCFDA, measures hydroxyl, peroxyl, and other ROS activity within the cell. Our data indicate that hypothermia effectively blocked $\mathrm{H}_{2} \mathrm{O}_{2}$ released from microglia, no matter when the hypothermia was initiated (as determined by Amplex Red in Figure 7). However, early-, co-, and delayed hypothermia showed differential effects on intracellular ROS production (as determined by DCFDA in Figure 8). As the inhibitory potency of hypothermia on neural cell death was similar among the different cellular assay systems (Figures 10, 11, 12, and 13), the neurotoxicity may be mainly caused by soluble toxic factors. Previous studies showed that TNF- $\alpha$, nitric oxide, IL-1 $\beta$, IL-6, MCP-1 glutamate, prostaglandins, and ROS are responsible for neurotoxicity [38,69-71].

In the brain injury region, activated microglia cells are presumed to migrate toward the tissue damage and transform into phagocytes [72,73]. Effects of hypothermia on the migration and phagocytic activity of the phagocytes have been previously investigated. Migration of human polymorphonuclear cells towards a chemotactic stimulus and their capacity for superoxide anion production was significantly reduced at $30{ }^{\circ} \mathrm{C}$. In another study, the phagocytic capacity of neutrophils for Staphylococcus aureus was impaired at $29{ }^{\circ} \mathrm{C}$ [74], and pig neutrophils and monocyte migration in vivo were also reduced at $29{ }^{\circ} \mathrm{C}$ [75]. Moreover, a previous study showed that moderate hypothermia resulted in a reduction in IL-1 $\beta$-induced leukocyte rolling and adhesion in the pial microvasculature of mice, providing neuroprotection [76]. Hypothermia downregulated the expression of migration inhibitory factor (MIF) in a rat model of traumatic brain injury [77]. Also, in an ischemia model, both intraischemic and delayed hypothermia decreased intercellular adhesion molecule-1 (ICAM-1) expression [78], which might play a significant role in cell extravasation and migration [79]. These previous findings are in agreement with the current results that hypothermia attenuates microglial migration in the Boyden chamber assay, wound healing assay, and rat stab injury model.

\section{Conclusions}

Our results show that therapeutic hypothermia exerts time-dependent effects on microglial activation and migration. Delayed hypothermia initiated after the inflammatory stimulation of the microglia in culture was able to attenuate the production of inflammatory mediators, thereby indicating that post-injury or -ischemic hypothermia may be therapeutically relevant to reduce deleterious neuroinflammation and secondary brain injuries.

\section{Abbreviations}

BBB: Blood-brain barrier; BrdU: 5-Bromo-2'-deoxyuridine; BSA: Bovine serum albumin; $\mathrm{CMH}_{2}$ DCFDA: 5-(and 6-) chloromethyl-2',7'dichlorodihydrofluorescein diacetate; Cy3: Cyanine Dye 3; CXCL10: C-X-C motif chemokine 10; CCL4: Chemokine (C-C motif) ligand 4; CCL20: Chemokine (C-C motif) ligand 20; CNS: Central nerve system; DAPI: 4',6-diamidino-2-phenylindole; DMEM: Dulbecco's modified Eagle's medium; DMSO: Dimethyl sulfoxide; EDTA: Ethylenediamine tetraacetic acid; EGFP: Enhanced green fluorescent protein; FBS: Fetal bovine serum;

FITC: Fluorescein isothiocyanate; GAPDH: Glyceraldehyde 3-phosphate dehydrogenase; HEPES: N-2-hydroxyethylpiperazine-N'-2-ethanesulfonic acid; HRP: Horseradish peroxidase; iNOS: Inducible NO synthase; IL-1 $\beta$ : Interleukin-1 beta; Iba-1: Ionized calcium binding adaptor molecule 1; IL-6: Interleukin-6; IL-12: Interleukin-12; LPS: Lipopolysaccharide; MCM: Microglia-conditioned media; MTT: 3-(4 5-dimethylthiazol-2-yl)-2, 5-diphenyltetrazolium bromide; NO: Nitric oxide; OCT: Optimal cutting temperature; PBS: Phosphate-buffered saline solution; PCNA: Proliferating Cell Nuclear Antigen; PFA: Paraformaldehyde; ROS: reactive oxygen species; RT-PCR: reverse transcriptase-polymerase chain reaction; SNP: Sodium nitroprusside; TNF-a: Tumor necrosis factor alpha; TLR4: Toll-like receptor 4.

\section{Competing interests}

The authors declare that they have no competing interests.

\section{Authors' contributions}

J-WS performed the experiments and analyzed the data as well as wrote the manuscript. Jong-Heon Kim and Jae-Hong Kim participated in animal studies. MS, HSH, and JP participated in the study design and data interpretation. KS is the main investigator of this work in charge of the study design, analysis and interpretation of results, and writing. All authors read and approved the final manuscript.

\section{Acknowledgments}

This work was supported by a grant from the Korea Healthcare technology R\&D Project, Ministry of Health \& Welfare, Republic of Korea (A100870), and by the National Research Foundation (NRF) grants funded by the Ministry of Education, Science and Technology (MEST) of Korean government (20110028240).

\section{Author details}

'Department of Pharmacology, Brain Science \& Engineering Institute, CMRI, Kyungpook National University School of Medicine, 101 Dong-In, Daegu, Joong-gu 700-422, South Korea. ²Department of Physiology, Brain Science \& Engineering Institute, Kyungpook National University School of Medicine, 
Daegu, South Korea. ${ }^{3}$ Department of Neurosurgery, Brain Science \& Engineering Institute, Kyungpook National University School of Medicine, Daegu, South Korea.

Received: 14 May 2012 Accepted: 14 June 2012

Published: 9 July 2012

\section{References}

1. Pedersen MO, Larsen A, Stoltenberg M, Penkowa M: Cell death in the injured brain: roles of metallothioneins. Prog Histochem Cytochem 2009, 44:1-27.

2. Lenzlinger PM, Morganti-Kossmann MC, Laurer HL, McIntosh TK: The duality of the inflammatory response to traumatic brain injury. Mol Neurobiol 2001, 24:169-181.

3. Baskaya MK, Rao AM, Dogan A, Donaldson D, Dempsey RJ: The biphasic opening of the blood-brain barrier in the cortex and hippocampus after traumatic brain injury in rats. Neurosci Lett 1997, 226:33-36.

4. Ceulemans AG, Zgavc T, Kooijman R, Hachimi-ldrissi S, Sarre S, Michotte Y: The dual role of the neuroinflammatory response after ischemic stroke: modulatory effects of hypothermia. J Neuroinflammation 2010, 7:74.

5. Simi A, Tsakiri N, Wang P, Rothwell NJ: Interleukin-1 and inflammatory neurodegeneration. Biochem Soc Trans 2007, 35:1122-1126.

6. Lelekov-Boissard T, Chapuisat G, Boissel JP, Grenier E, Dronne MA: Exploration of beneficial and deleterious effects of inflammation in stroke: dynamics of inflammation cells. Philos Transact A Math Phys Eng Sci 2009, 367:4699-4716.

7. Arvin B, Neville LF, Barone FC, Feuerstein GZ: The role of inflammation and cytokines in brain injury. Neurosci Biobehav Rev 1996, 20:445-452.

8. Batchelor PE, Tan S, Wills TE, Porritt MJ, Howells DW: Comparison of inflammation in the brain and spinal cord following mechanical injury. J Neurotrauma 2008, 25:1217-1225.

9. McGeer EG, McGeer PL: Inflammatory processes in Alzheimer's disease. Prog Neuropsychopharmacol Biol Psychiatry 2003, 27:741-749.

10. Graeber MB, Streit WJ: Microglia: biology and pathology. Acta Neuropathol 2010, 119:89-105.

11. Marion DW, Penrod LE, Kelsey SF, Obrist WD, Kochanek PM, Palmer AM, Wisniewski SR, DeKosky ST: Treatment of traumatic brain injury with moderate hypothermia. N Eng/ J Med 1997, 336:540-546.

12. Dietrich WD, Bramlett HM: The evidence for hypothermia as a neuroprotectant in traumatic brain injury. Neurotherapeutics 2010, 7:43-50

13. Carey HV, Andrews MT, Martin SL: Mammalian hibernation: cellular and molecular responses to depressed metabolism and low temperature. Physiol Rev 2003, 83:1153-1181.

14. Yenari MA, Han HS: Neuroprotective mechanisms of hypothermia in brain ischaemia. Nat Rev Neurosci 2012, 13:267-278.

15. Diestel A, Troeller S, Billecke N, Sauer IM, Berger F, Schmitt KR: Mechanisms of hypothermia-induced cell protection mediated by microglial cells in vitro. Eur J Neurosci 2010, 31:779-787.

16. Tymianski M, Sattler R, Zabramski JM, Spetzler RF: Characterization of neuroprotection from excitotoxicity by moderate and profound hypothermia in cultured cortical neurons unmasks a temperatureinsensitive component of glutamate neurotoxicity. J Cereb Blood Flow Metab 1998, 18:848-867.

17. Matsui T, Motoki $Y$, Inomoto T, Miura D, Kato Y, Suenaga H, Hino K, Nojima $\mathrm{J}$ : Temperature-related effects of adenosine triphosphate-activated microglia on pro-inflammatory factors. Neurocrit Care, in press.

18. Gibbons H, Sato TA, Dragunow M: Hypothermia suppresses inducible nitric oxide synthase and stimulates cyclooxygenase-2 in lipopolysaccharide stimulated BV-2 cells. Brain Res Mol Brain Res 2003, 110:63-75.

19. Maekawa S, Aibiki M, Si QS, Nakamura Y, Shirakawa Y, Kataoka K: Differential effects of lowering culture temperature on mediator release from lipopolysaccharide-stimulated neonatal rat microglia. Crit Care Med 2002, 30:2700-2704

20. Han HS, Karabiyikoglu M, Kelly S, Sobel RA, Yenari MA: Mild hypothermia inhibits nuclear factor-kappaB translocation in experimental stroke. J Cereb Blood Flow Metab 2003, 23:589-598.

21. Han HS, Qiao Y, Karabiyikoglu M, Giffard RG, Yenari MA: Influence of mild hypothermia on inducible nitric oxide synthase expression and reactive nitrogen production in experimental stroke and inflammation. J Neurosci 2002, 22:3921-3928.
22. Karabiyikoglu M, Han HS, Yenari MA, Steinberg GK: Attenuation of nitric oxide synthase isoform expression by mild hypothermia after focal cerebral ischemia: variations depending on timing of cooling. J Neurosurg 2003, 98:1271-1276

23. Askalan R, Wang C, Shi H, Armstrong E, Yager JY: The effect of postischemic hypothermia on apoptotic cell death in the neonatal rat brain. Dev Neurosci 2011, 33:320-329.

24. Zhao H, Shimohata T, Wang JQ, Sun G, Schaal DW, Sapolsky RM, Steinberg GK: Akt contributes to neuroprotection by hypothermia against cerebral ischemia in rats. J Neurosci 2005, 25:9794-9806.

25. Al-Fageeh MB, Smales CM: Cold-inducible RNA binding protein (CIRP) expression is modulated by alternative mRNAs. RNA 2009, 15:1164-1176.

26. Maier CM, Sun GH, Kunis D, Yenari MA, Steinberg GK: Delayed induction and long-term effects of mild hypothermia in a focal model of transient cerebral ischemia: neurological outcome and infarct size. J Neurosurg 2001, 94:90-96.

27. Tang XN, Yenari MA: Hypothermia as a cytoprotective strategy in ischemic tissue injury. Ageing Res Rev 2010, 9:61-68.

28. Wolff B, Machill K, Schumacher D, Schulzki I, Werner D: Early achievement of mild therapeutic hypothermia and the neurologic outcome after cardiac arrest. Int I Cardiol 2009, 133:223-228.

29. Block ML, Zecca L, Hong JS: Microglia-mediated neurotoxicity: uncovering the molecular mechanisms. Nat Rev Neurosci 2007, 8:57-69.

30. Saura J, Tusell JM, Serratosa J: High-yield isolation of murine microglia by mild trypsinization. Glia 2003, 44:183-189.

31. McCarthy KD, de Vellis J: Preparation of separate astroglial and oligodendroglial cell cultures from rat cerebral tissue. J Cell Biol 1980, 85:890-902.

32. Schubert D, Heinemann S, Carlisle W, Tarikas H, Kimes B, Patrick J, Steinbach $J H$, Culp W, Brandt BL: Clonal cell lines from the rat central nervous system. Nature 1974, 249:224-227.

33. Lee S, Jang E, Kim JH, Kim JH, Lee WH, Suk K: Lipocalin-type prostaglandin D2 synthase protein regulates glial cell migration and morphology through myristoylated alanine-rich C-kinase substrate: prostaglandin D2-independent effects. J Biol Chem 2012, 287:9414-9428.

34. Ock J, Jeong J, Choi WS, Lee WH, Kim SH, Kim IK, Suk K: Regulation of Toll-like receptor 4 expression and its signaling by hypoxia in cultured microglia. J Neurosci Res 2007, 85:1989-1995.

35. Lee S, Suk K: Heme oxygenase-1 mediates cytoprotective effects of immunostimulation in microglia. Biochem Pharmacol 2007, 74:723-729.

36. Lee S, Park JY, Lee WH, Kim H, Park HC, Mori K, Suk K: Lipocalin-2 is an autocrine mediator of reactive astrocytosis. J Neurosci 2009, 29:234-249.

37. Ock J, Han HS, Hong SH, Lee SY, Han YM, Kwon BM, Suk K: Obovatol attenuates microglia-mediated neuroinflammation by modulating redox regulation. Br J Pharmacol 2010, 159:1646-1662.

38. Gibbons HM, Dragunow M: Microglia induce neural cell death via a proximity-dependent mechanism involving nitric oxide. Brain Res 2006, 1084:1-15.

39. Zhou M, Diwu Z, Panchuk-Voloshina N, Haugland RP: A stable nonfluorescent derivative of resorufin for the fluorometric determination of trace hydrogen peroxide: applications in detecting the activity of phagocyte NADPH oxidase and other oxidases. Anal Biochem 1997, 253:162-168.

40. Greenlund LJ, Deckwerth TL, Johnson EM Jr: Superoxide dismutase delays neuronal apoptosis: a role for reactive oxygen species in programmed neuronal death. Neuron 1995, 14:303-315.

41. Lee S, Kim JH, Kim JH, Seo JW, Han HS, Lee WH, Mori K, Nakao K, Barasch J, Suk K: Lipocalin-2 is a chemokine inducer in the central nervous system: role of chemokine ligand 10 (CXCL10) in lipocalin-2-induced cell migration. J Biol Chem 2011, 286:43855-43870.

42. Liang CC, Park AY, Guan JL: In vitro scratch assay: a convenient and inexpensive method for analysis of cell migration in vitro. Nat Protoc 2007, 2:329-333.

43. Bassi R, Giussani P, Anelli V, Colleoni T, Pedrazzi M, Patrone M, Viani P, Sparatore B, Melloni E, Riboni L: HMGB1 as an autocrine stimulus in human T98G glioblastoma cells: role in cell growth and migration. J Neurooncol 2008, 87:23-33.

44. Clark DL, Colbourne F: A simple method to induce focal brain hypothermia in rats. J Cereb Blood Flow Metab 2007, 27:115-122. 
45. Block ML, Hong JS: Microglia and inflammation-mediated neurodegeneration: multiple triggers with a common mechanism. Prog Neurobiol 2005, 76:77-98.

46. Polderman $\mathrm{KH}$ : Mechanisms of action, physiological effects, and complications of hypothermia. Crit Care Med 2009, 37:S186-202.

47. Yunoki M, Nishio S, Ukita N, Anzivino MJ, Lee KS: Hypothermic preconditioning induces rapid tolerance to focal ischemic injury in the rat. Exp Neurol 2003, 181:291-300.

48. Yuan HB, Huang Y, Zheng S, Zuo Z: Hypothermic preconditioning increases survival of purkinje neurons in rat cerebellar slices after an in vitro simulated ischemia. Anesthesiology 2004, 100:331-337.

49. Hirsch AT, Haskal ZJ, Hertzer NR, Bakal CW, Creager MA, Halperin JL, Hiratzka LF, Murphy WR, Olin JW, Puschett JB, Rosenfield KA, Sacks D, Stanley JC, Taylor LM Jr, White CJ, White J, White RA, Antman EM, Smith SC Jr, Adams $C D$, Anderson JL, Faxon DP, Fuster V, Gibbons RJ, Hunt SA, Jacobs AK, Nishimura R, Ornato JP, Page RL, Riegel B: ACC/AHA 2005 Practice Guidelines for the management of patients with peripheral arterial disease. Circulation 2006, 113:e463-654.

50. MacLellan CL, Clark DL, Silasi G, Colbourne F: Use of prolonged hypothermia to treat ischemic and hemorrhagic stroke. J Neurotrauma 2009, 26:313-323.

51. Shpargel KB, Jalabi W, Jin Y, Dadabayev A, Penn MS, Trapp BD: Preconditioning paradigms and pathways in the brain. Cleve Clin J Med 2008, 75(Suppl 2):S77-82.

52. Ohta $H$, Terao $Y$, Shintani $Y$, Kiyota $Y$ : Therapeutic time window of postischemic mild hypothermia and the gene expression associated with the neuroprotection in rat focal cerebral ischemia. Neurosci Res 2007, 57:424-433.

53. David HN, Haelewyn B, Chazalviel L, Lecocq M, Degoulet M, Risso JJ, Abraini $\mathrm{JH}$ : Post-ischemic helium provides neuroprotection in rats subjected to middle cerebral artery occlusion-induced ischemia by producing hypothermia. J Cereb Blood Flow Metab 2009, 29:1159-1165.

54. Colbourne F, Corbett D, Zhao Z, Yang J, Buchan AM: Prolonged but delayed postischemic hypothermia: a long-term outcome study in the rat middle cerebral artery occlusion model. J Cereb Blood Flow Metab 2000, 20:1702-1708

55. Nagel S, Papadakis M, Pfleger K, Grond-Ginsbach C, Buchan AM, Wagner S: Microarray analysis of the global gene expression profile following hypothermia and transient focal cerebral ischemia. Neuroscience 2012, 208:109-122.

56. Baker CJ, Onesti ST, Solomon RA: Reduction by delayed hypothermia of cerebral infarction following middle cerebral artery occlusion in the rat: a time-course study. J Neurosurg 1992, 77:438-444.

57. Moyer DJ, Welsh FA, Zager EL: Spontaneous cerebral hypothermia diminishes focal infarction in rat brain. Stroke 1992, 23:1812-1816.

58. Kader A, Brisman MH, Maraire N, Huh JT, Solomon RA: The effect of mild hypothermia on permanent focal ischemia in the rat. Neurosurgery 1992, 31:1056-1060. discussion 1060-1051.

59. Xue D, Huang ZG, Smith KE, Buchan AM: Immediate or delayed mild hypothermia prevents focal cerebral infarction. Brain Res 1992, 587:66-72.

60. Zhang RL, Chopp M, Chen H, Garcia JH, Zhang ZG: Postischemic (1 hour) hypothermia significantly reduces ischemic cell damage in rats subjected to 2 hours of middle cerebral artery occlusion. Stroke 1993, 24:1235-1240

61. Yanamoto H, Hong SC, Soleau S, Kassell NF, Lee KS: Mild postischemic hypothermia limits cerebral injury following transient focal ischemia in rat neocortex. Brain Res 1996, 718:207-211.

62. Kollmar R, Schabitz WR, Heiland S, Georgiadis D, Schellinger PD, Bardutzky J, Schwab S: Neuroprotective effect of delayed moderate hypothermia after focal cerebral ischemia: an MRI study. Stroke 2002, 33:1899-1904.

63. Matsui T, Kakeda T: IL-10 production is reduced by hypothermia but augmented by hyperthermia in rat microglia. J Neurotrauma 2008, 25:709-715.

64. Hagiwara S, Iwasaka H, Matsumoto S, Noguchi T: Changes in cell culture temperature alter release of inflammatory mediators in murine macrophagic RAW264.7 cells. Inflamm Res 2007, 56:297-303.

65. Gundersen Y, Vaagenes P, Pharo A, Valo ET, Opstad PK: Moderate hypothermia blunts the inflammatory response and reduces organ injury after acute haemorrhage. Acta Anaesthesio/ Scand 2001, 45:994-1001.
66. Seko Y, Cole S, Kasprzak W, Shapiro BA, Ragheb JA: The role of cytokine mRNA stability in the pathogenesis of autoimmune disease. Autoimmun Rev 2006, 5:299-305.

67. Hollams EM, Giles KM, Thomson AM, Leedman PJ: MRNA stability and the control of gene expression: implications for human disease. Neurochem Res 2002, 27:957-980.

68. Clark A: Post-transcriptional regulation of pro-inflammatory gene expression. Arthritis Res 2000, 2:172-174.

69. Chang RC, Hudson P, Wilson B, Haddon L, Hong JS: Influence of neurons on lipopolysaccharide-stimulated production of nitric oxide and tumor necrosis factor-alpha by cultured glia. Brain Res 2000, 853:236-244.

70. Lee M, Suk K, Kang Y, McGeer E, McGeer PL: Neurotoxic factors released by stimulated human monocytes and THP-1 cells. Brain Res 2011, 1400:99-111.

71. Hinojosa AE, Garcia-Bueno B, Leza JC, Madrigal JL: CCL2/MCP-1 modulation of microglial activation and proliferation. J Neuroinflammation 2011, 8:77.

72. Aloisi F: Immune function of microglia. Glia 2001, 36:165-179.

73. Gehrmann J, Matsumoto Y, Kreutzberg GW: Microglia: intrinsic immuneffector cell of the brain. Brain Res Brain Res Rev 1995, 20:269-287.

74. Salman H, Bergman M, Bessler H, Alexandrova S, Beilin B, Djaldetti M: Hypothermia affects the phagocytic activity of rat peritoneal macrophages. Acta Physio/ Scand 2000, 168:431-436.

75. Biggar WD, Bohn DJ, Kent G, Barker C, Hamilton G: Neutrophil migration in vitro and in vivo during hypothermia. Infect Immun 1984, 46:857-859.

76. Sutcliffe IT, Smith HA, Stanimirovic D, Hutchison JS: Effects of moderate hypothermia on IL-1 beta-induced leukocyte rolling and adhesion in pial microcirculation of mice and on proinflammatory gene expression in human cerebral endothelial cells. J Cereb Blood Flow Metab 2001, 21:1310-1319

77. Truettner JS, Suzuki T, Dietrich WD: The effect of therapeutic hypothermia on the expression of inflammatory response genes following moderate traumatic brain injury in the rat. Brain Res Mol Brain Res 2005, 138:124-134.

78. Merrill JE, Benveniste EN: Cytokines in inflammatory brain lesions: helpful and harmful. Trends Neurosci 1996, 19:331-338.

79. Deng $H$, Han HS, Cheng D, Sun GH, Yenari MA: Mild hypothermia inhibits inflammation after experimental stroke and brain inflammation. Stroke 2003, 34:2495-2501.

doi:10.1186/1742-2094-9-164

Cite this article as: Seo et al:: Time-dependent effects of hypothermia on microglial activation and migration. Journal of Neuroinflammation 2012 9:164.

\section{Submit your next manuscript to BioMed Central and take full advantage of:}

- Convenient online submission

- Thorough peer review

- No space constraints or color figure charges

- Immediate publication on acceptance

- Inclusion in PubMed, CAS, Scopus and Google Scholar

- Research which is freely available for redistribution 